Ife Journal of Science vol. 20, no. 3 (2018)

\title{
DISTRIBUTION PATTERNS OF TRACE METALS IN SOILS OF GBONGAN- ORILEOWU AREA, SOUTHWESTERN NIGERIA
}

\author{
Adesiyan, T. A. ${ }^{1}$, Adekoya, J. A. ${ }^{2}$ and *Alao-Daniel, A. B. ${ }^{1}$ \\ ${ }^{1}$ Department of Geology, Obafemi Awolowo University, Ile -Ife, Nigeria \\ ${ }^{2}$ Department of Geology, Osun State University, Oshogbo, Nigeria \\ *Corresponding Author: adedamolaalaodaniel@oauife.edu.ng \\ (Received: $1^{\text {st }}$ June, 2018; Accepted: $28^{\text {th }}$ September, 2018)
}

ABSTRACT

\begin{abstract}
One hundred and eighty six (186) in situ soil samples of the B - horizon were collected around GbonganOrileowu area of Osun State, Southwestern Nigeria for a reconnaissance geochemical soil survey. The objective was to determine the distribution pattern of some trace metals in the area with a view to discovering any indication of metallic mineralization and possible correlation with the underlying bedrock. The samples were air-dried and sieved to obtain the minus 230 micron fractions which were split into two portions for hot aqua regia acid digestion and $\mathrm{pH}$ determinations. The solutions obtained from the digestion were analyzed for $\mathrm{Ag}$, As, $\mathrm{Au}, \mathrm{Cd}, \mathrm{Co}, \mathrm{Cr}, \mathrm{Cu}, \mathrm{Fe}, \mathrm{Mn}, \mathrm{Ni}, \mathrm{Pb}, \mathrm{Sn}$, and Zn using Atomic Absorption Spectrometric methods. The resulting data were used in preparing distribution maps of the elements in the study area, employing the location point symbol method. Simple statistical treatment was also carried out on the data to determine the mean and standard deviation for each element. With these, the spatial distributions of the trace elements in the area were discussed. The $\mathrm{pH}$ of the soils range from 4.70 to 7.59 and this reflects the geochemical distribution patterns of trace metals in the area. The spatial distribution maps of the elements showed similarity in the distributions of $\mathrm{Co}, \mathrm{Cr}, \mathrm{Fe}, \mathrm{Ni}, \mathrm{Mn}$ and $\mathrm{Pb}$. This suggests close associations between these elements none of which showed any significant anomaly. The association might be due to the scavenging actions of Fe-Mn oxides on the other elements. $\mathrm{Ag}, \mathrm{Au}$ and $\mathrm{Sn}$ on one hand and $\mathrm{Zn}$ on the other hand showed significant anomalies, which were thought to be due to mineralization and anthropogenic activities respectively. As, $\mathrm{Co}, \mathrm{Cu}, \mathrm{Fe}, \mathrm{Ni}$ and $\mathrm{Pb}$ probably occur as sulphides within reported underlying ultramafic rocks or Au bearing quartz veins or both. It is probable that $\mathrm{Au}$ and $\mathrm{Ag}$ occur as disseminations within the ultramafic rocks, aside from their occurrence in the veins, while $\mathrm{Sn}$ is most probably from the pegmatites. The very high $\mathrm{Zn}$ in the area is probably due to contamination.
\end{abstract}

Keywords: Significant anomalies, Ultramafic, Anthropogenic, Mineralization

\section{INTRODUCTION}

The presence of high degree of weathering, which usually gives rise to formation of thick overburden, and widespread occurrence of dense vegetation cover in the tropical rain and equatorial forest areas, constitutes important obstacles to geological mapping. These features result in a low outcrop density, which hampers direct prospecting for minerals or preparation of an accurate geological map. Geochemical techniques have been shown to be capable of playing an important role in a regional reconnaissance survey of such areas (Freyssinet,1993; Key et al., 2004; Adesiyan et al., 2014 and Owoeye et al., 2015). Key et al. (2004) and Owoeye (2012) emphasized the suitability of geochemical techniques for geological mapping and exploration in Nigeria, a tropical country, sometimes devoid of outcrops over wide areas owing to huge overburden.
Soil surveys are widely used in geochemical exploration and very successful results have been achieved especially with surveys conducted on residual soils. Their success is based on the fact that during the process of weathering and leaching, anomalous concentration of elements from underlying mineralization/rock may become incorporated in the soil, as well as in other weathering products and in groundwater (Morsy, 1995; Alexakis, 2008 and Knight et al., 2011). Thus, the characteristic dispersion pattern in a soil is a reflection of the parent rock, the concealed ores and the effect of environmental factors. Adesiyan (2010) and Knight et al. (2011) concluded that the strength of residual anomalies over restricted areas might be directly related to the grade of mineralization in the underlying bedrock.

A reconnaissance geochemical soil survey of Gbongan-Odeyinka-Orileowu area of Osun State was carried out. The area is delineated by 
longitude $4^{\circ} 15^{\prime}$ and $4^{\circ} 30^{\prime} \mathrm{E}$ and latitude $7^{\circ} 14^{\prime}$ and $7^{0} 31^{1} \mathrm{~N}$; a thickly forested tropical region (Fig. 1). Residual soil is the geochemical sample most often employed after stream sediment in geochemical surveys. It is more appropriately used in detailed study. However, because of its relatively high dependability, it can also be employed in reconnaissance survey. In this study, reconnaissance geochemical soil survey is applied as a follow up of the reconnaissance geochemical stream sediment surveys earlier carried out in parts of the area (Alao, 2003; Adesiyan and Adekoya, 2008 and Adesiyan et al., 2014). The soil survey is aimed at defining more precisely and isolating areas of high metallic mineralization potential that can possibly be traced to the primary mineralization, if any, in the underlying bedrock.

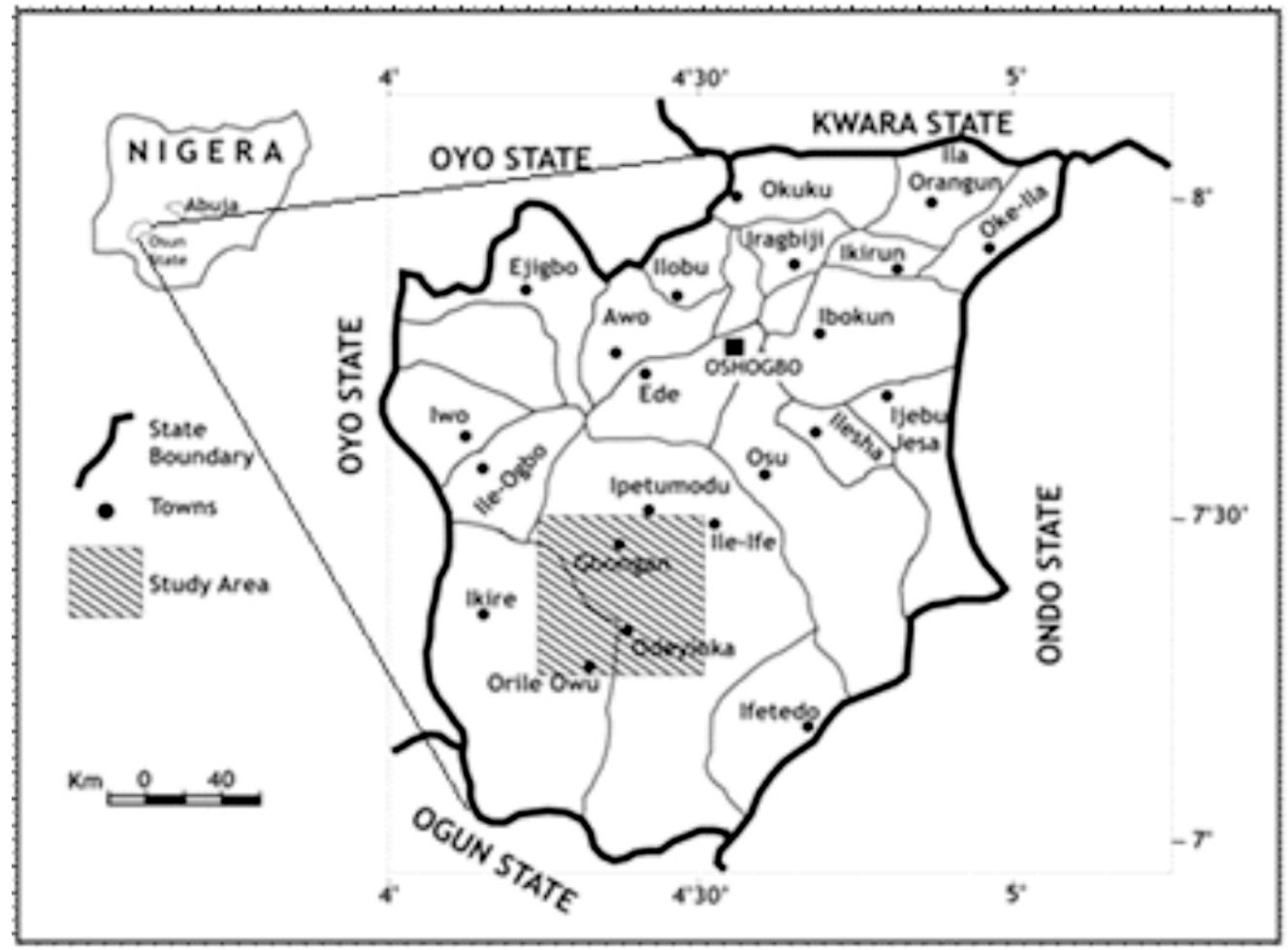

Figure 1: Map of Osun State showing Gbongan-Odeyinka-Orileowu Area.

\section{GEOLOGICAL SETTING}

The study area lies in the Precambrian crystalline Basement Complex of Southwestern Nigeria, which consists of a wide variety of metamorphic and igneous rocks and has been shown to be polycyclic, with isotopic ages ranging from 2800 Ma to $4500 \mathrm{Ma}$ (Rahaman, 1988; Dada, 2006 and Adetunji et al., 2016). It forms part of the PanAfrican mobile belt situated east of the West African Craton and west of the Congo Craton.

A number of workers have tried to group the wide varieties of rocks of the Nigerian Basement Complex into different divisions. Adekoya et al. (2003) gave a four - fold tectono-stratigraphic divisions and the main features of these rocks have been discussed in details. This seems to explain best the field associations and age relationship among the lithologic units, namely (i) Migmatite-Gneiss-Complex of Archaean to Early Proterozoic; (ii) the Proterozoic Schist Belts; (iii) the Pan African Granites and associated granitoids; and (iv) late Neoproterozoic to Early Palaeozoic minor felsic and mafic intrusives.

However, the Basement Complex rocks underlying the area (Fig. 2) as shown on the geological map of Iwo region (de Swardt et al., 1965) consist of various rock types. Of the nine rock units, the pegmatitised schists cover the greater part of the area occurring around the central portion, the southwestern and southeastern portions and trending in the northsouth direction. Following the pegmatitised 
schists in area extent are both undifferentiated gneisses and migmatite and pegmatite, which appear to occur in almost equal proportions. The migmatite trends north - south in the western part of the study area with a portion occurring within the pegmatitised schists around the north central part while the pegmatite, which appears as intrusions within the pegmatitised schists underlies parts of the eastern and southern area of the map (Fig. 2). Granite gneiss occurs in the eastern part and around the pegmatite, giving the impression of being intruded by the latter. Other rock types occur in minor proportions and these include the undifferentiated schists with some gneiss in the northeastern part and granodiorite, biotite and biotite-muscovite granite, porphyritic granite and charnockitic meta-intrusives, all in the north western part.

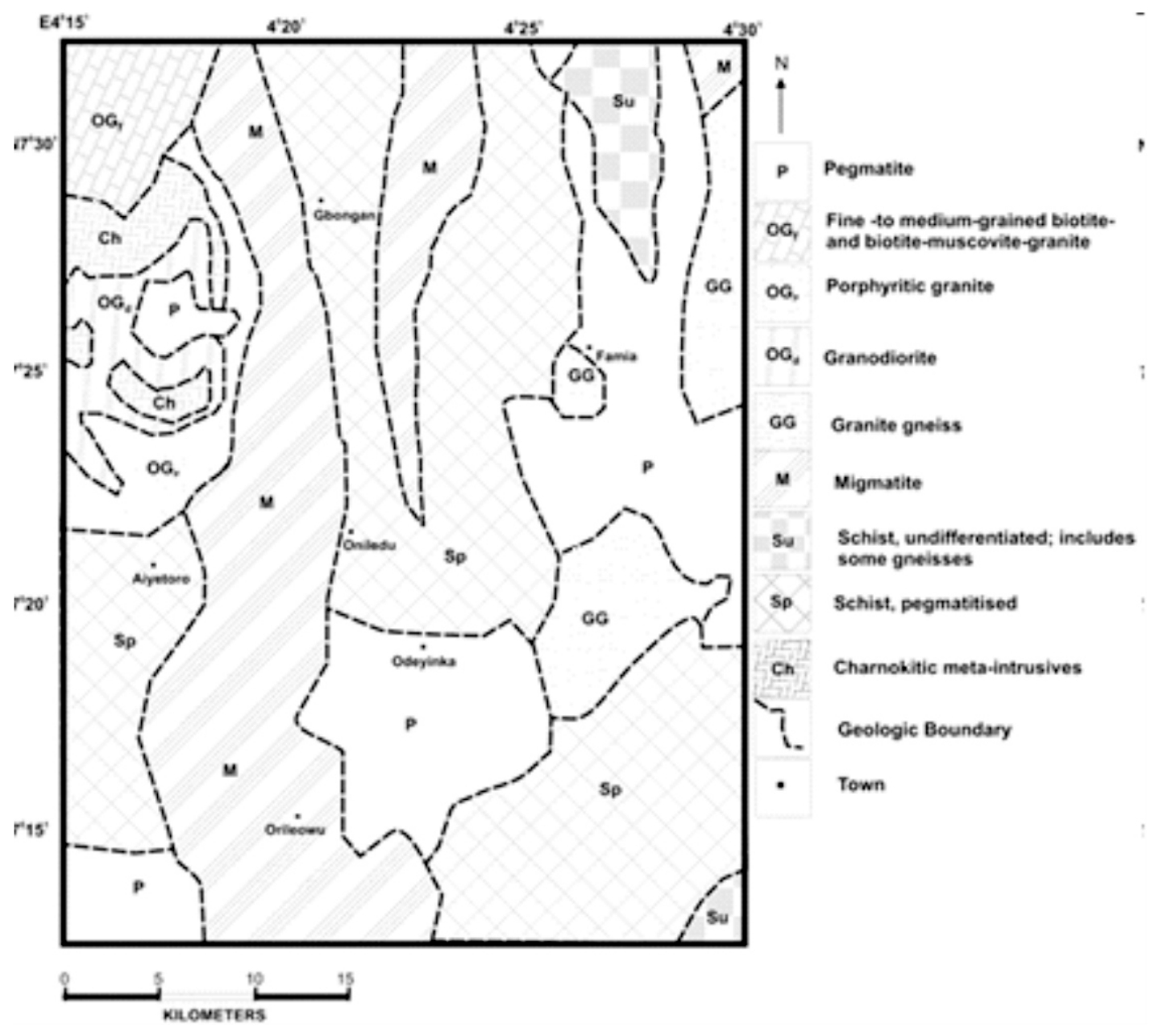

Figure 2: Geological Map of Gbongan-Odeyinka-Orileowu Area.

\section{MATERIALS AND METHODS}

In this study, 186 in situ soil samples of the B horizon were collected from an area of approximately seven hundred and sixty square kilometers (Fig. 2). The B-Horizon of the soil profile was preferred for sampling because of the thickness of C-Horizon in the tropical region and a recent investigation by Arisekola et al. (2011) of the Nigeria Geological Survey Agency in a closer area also shows that B-Horizon can also give good results. The samples were taken at intervals of between $500 \mathrm{~m}$ and $1000 \mathrm{~m}$ in such a way as to avoid rocky ground, areas close to river valleys, settlements, refuse dumps and other possible sources of contamination. The sampling was based on a 1:50,000 topographic map, sheet 262 (Apomu NE) and the actual sampling points were determined using the Global Positioning System (GPS).

The samples were air dried, disaggregated and sieved with a 230 micron nylon sieve. The 
fractions passing the sieve were then reserved for digestion and determination of $\mathrm{pH}$. Measurement of the $\mathrm{pH}$ of each of the samples was performed at room temperature in soil/water suspensions at soil to water ratio of 1:3 using ultra-pure deionized water. The soil/water suspensions were shaken with a Stuart Scientific SF1 Flask Shaker for 30 minutes and then allowed to equilibrate for another 30 minutes. The $\mathrm{pH}$ meter (Orion $420 \mathrm{~A}$ plus) was standardized at $\mathrm{pH} 4.0$ and 7.0 , and the meter electrode was inserted in the suspensions while the latter were being shaken. The measurements were taken when stable $\mathrm{pH}$ readings were obtained (modified after Mosetlha, 2007).

One gramme $(1.0 \mathrm{~g})$ of each of the samples was digested with $10 \mathrm{~mL}$ of aqua regia (mixture of $\mathrm{HCl}$ and $\mathrm{HNO}_{3}$ in ratio $\left.3: 1\right)$ on hot plate $\left(70{ }^{\circ} \mathrm{C}\right.$ $\pm 15{ }^{\circ} \mathrm{C}$ ) for 1 hour and filtered into $25 \mathrm{~mL}$ volumetric flask, which was made up to mark with ultra-pure deionized water. The resulting solutions from the digestion were analysed for Ag, $\mathrm{Co}, \mathrm{Cr}, \mathrm{Cu}, \mathrm{Fe}, \mathrm{Mn}, \mathrm{Ni}, \mathrm{Pb}, \mathrm{Sn}$ and $\mathrm{Zn}$ using the Varian Spectra AA Flame Atomic Absorption Spectrometer and for As, Au and Cd using the Shimadzu AA-6800 platform type graphite furnace Atomic Absorption Spectrometer equipped with deuterium background corrector at the Department of Chemistry, University of Botswana, Gaborone, Botswana. Analytical precision and accuracy were determined by the analysis of duplicates, repeated analysis of some samples where necessary and insertion of standard solutions as checking standards at intervals of 50 samples. Both precision and accuracy were reasonable and satisfactory.

\section{RESULTS AND DISCUSSION}

The data obtained for the 13 trace elements determined in the 186 soil samples collected for this study, were subjected to simple statistical treatment to obtain some basic statistical parameters (see details in Adesiyan et al., 2014). From these parameters, the threshold values for the elements were calculated (Table 1). Threshold, according to Levinson (1974), is the upper limit of normal background values, background itself being the normal range of concentrations for an element or elements in an area. In exploration geochemistry, the determination of threshold is important because it is the value above which the concentration of any element is considered anomalous.

The analytical data were also used to prepare location point symbol map for each of the elements; to facilitate visual enhancement of the spatial distribution patterns of the elements in the study area.

\section{$\mathrm{pH}$ of the Soils}

The solubility of most elements and the stability of their compounds are extremely sensitive to the $\mathrm{pH}$ of the aqueous environment. Only a few elements are normally soluble throughout the entire $\mathrm{pH}$ range. Most metallic elements are soluble only in acid solutions and tend to precipitate as hydroxides (or basic salts) with increasing $\mathrm{pH}$ (Adesiyan, 2010 and Knight et al., 2011).

In this study, the $\mathrm{pH}$ of the soil samples ranges between 4.70 in location 172 (underlain by granite gneiss) and 7.59 in location 28 (underlain by pegmatitised schists). However a $\mathrm{pH}$ of $6.00-6.99$ recorded the highest frequency, covering $78.0 \%$ of the values. About $92.5 \%$ of the soil samples have $\mathrm{pH}$ values that range from $4.70-6.99$ and the remaining $7.5 \%$ reveals values of between 7.00 and 7.59. Thus, it can be inferred that the $\mathrm{pH}$ of soils of the study area is largely weakly acidic.

Various workers, notably, Kehinde-Philips and Tiez (1995), Knight et al. (2011) and Adesiyan et al. (2014) have reported the role of $\mathrm{pH}$ in controlling the solubility and precipitation of elements in an aqueous environment. For example, $\mathrm{Cu}, \mathrm{Pb}, \mathrm{Zn}, \mathrm{Ni}$ and $\mathrm{Ag}$ go into solution under acidic conditions (low $\mathrm{pH}$ ) but are precipitated under high $\mathrm{pH}$. The analytical results of soils of the study area confirm this observation. For instance, $\mathrm{Cu}$ recorded a low concentration of $3.5 \mathrm{ppm}$ at location 172 where the $\mathrm{pH}$ is 4.7 whereas it has a high concentration of $102.0 \mathrm{ppm}$ at location 13 where the $\mathrm{pH}$ is 6.7. For $\mathrm{Ni}$, a high concentration of $126.3 \mathrm{ppm}$ was recorded at location 85 where the $\mathrm{pH}$ is 6.7 while a low concentration of $11.9 \mathrm{ppm}$ was obtained at location 150 where the $\mathrm{pH}$ is 5.2. On the basis of the foregoing, it can be deduced that the geochemical distribution patterns of the elements in the soil of the study area reflects the prevailing $\mathrm{pH}$ conditions of the soils. 
Table 1 : Summary of basic statistical parameters for screened raw soil geochemical data of the study area

\begin{tabular}{|c|c|c|c|c|c|c|}
\hline Elements & $\begin{array}{l}\text { Range of Metal } \\
\text { Concentrations } \\
\text { in ppm }\end{array}$ & $\begin{array}{l}\text { Arithmetic } \\
\text { Mean } \\
\text { Values } \bar{X}\end{array}$ & Median & $\begin{array}{l}\text { Standard } \\
\text { Deviation }\end{array}$ & $\begin{array}{l}\text { Threshold } \\
=(\bar{X}+2 S)\end{array}$ & $\begin{array}{c}\text { Coefficient } \\
\text { of } \\
\text { Variation }\end{array}$ \\
\hline $\mathrm{Ag}$ & $0.02-7.36$ & 2.41 & 2.24 & 1.50 & 5.41 & 62 \\
\hline *As & $6.38-5795.17$ & 1056.41 & 772.92 & 992.72 & 3041.85 & 94 \\
\hline$* \mathrm{Au}$ & $0.17-162.64$ & 18.40 & 9.65 & 24.63 & 67.66 & 137 \\
\hline$* \mathrm{Cd}$ & $0.26-404.25$ & 50.90 & 27.27 & 65.76 & 182.42 & 129 \\
\hline Co & $2.06-352.45$ & 44.00 & 25.82 & 52.16 & 148.32 & 119 \\
\hline $\mathrm{Cr}$ & $0.33-246.71$ & 29.36 & 17.11 & 36.86 & 103.08 & 126 \\
\hline $\mathrm{Cu}$ & $2.38-102.03$ & 25.10 & 22.53 & 16.92 & 58.94 & 67 \\
\hline$* * \mathrm{Fe}$ & $0.79-10.51$ & 4.16 & 3.90 & 1.91 & 7.98 & 46 \\
\hline $\mathrm{Mn}$ & $12.98-9460.63$ & 1039.29 & 575.97 & 1539.54 & 4118.37 & 148 \\
\hline $\mathrm{Ni}$ & $0.63-126.32$ & 19.85 & 16.99 & 14.98 & 49.81 & 75 \\
\hline $\mathrm{Pb}$ & $2.78-186.79$ & 36.80 & 31.55 & 27.99 & 92.78 & 76 \\
\hline $\mathrm{Sn}$ & $0.18-171.58$ & 57.66 & 40.79 & 47.30 & 152.26 & 82 \\
\hline $\mathrm{Zn}$ & $3.55-7085.36$ & 510.75 & 242.37 & 897.46 & 2305.67 & 176 \\
\hline
\end{tabular}

* - Given in ppb

** - Given in $\%$

Distribution of Elements

Certain chemical elements show a marked affinity for rocks with a basic or ultra-basic character while others are relatively enriched in acid rocks (Key et al., 2004; and Reimann and Garrette, 2005). Thus, one can infer that the trace element contents in superficial materials like soils are more or less directly linked to the composition of the underlying bedrock. Therefore, there is the possibility of utilizing the results of multi-element soil geochemical prospecting to define the geology of an area, apart from its usefulness in delineating areas of economic mineral prospect. The metal contents of the soils in the study area as it would be seen later show considerable variations from one area to the other. Despite this, certain broad characteristic distribution patterns of the elements can be observed. To this end, the distribution of trace elements in the study area is discussed using the location point symbol maps for illustrations. The maps are super-imposed on the geological map of the area to aid the description of elemental distribution. The mean value of each of the elements is compared with the average abundance of the element in the soil, earth crust and some rock types (Table 2) to consider the significance of the elements in the study area. 
Table 2: Average abundance of elements in the earth's crust, ultramafic rocks, soil, granite and granodiorite. (After Levinson, 1974 and Rose, et al., 1979)

(All values in ppm except for As, $\mathrm{Au}$ and $\mathrm{Cd}$ which are in $\mathrm{ppb}$ and Fe in Percentage)

\begin{tabular}{|c|c|c|c|c|c|c|}
\hline Element & Earth's Crust & Ultramafic/Mafic & Granite & Granodiorite & Soil & Mean values \\
\hline $\mathrm{Ag}$ & 0.07 & 0.06 & 0.04 & 0.07 & 0.1 & 2.41 \\
\hline $\mathrm{As}$ & 1800 & 1000 & 1500 & 2000 & $1000-50000$ & 1056.41 \\
\hline $\mathrm{Au}$ & 4 & 5 & 4 & 4 & 2 & 18.40 \\
\hline $\mathrm{Cd}$ & 200 & 200 & 200 & 200 & $100-500$ & 50.90 \\
\hline $\mathrm{Co}$ & 25 & 150 & 1 & 10 & $1-40$ & 44.00 \\
\hline $\mathrm{Cr}$ & 100 & 2000 & 4 & 20 & $5-1000$ & 29.36 \\
\hline $\mathrm{Cu}$ & 55 & 10 & 10 & 30 & $2-100$ & 25.10 \\
\hline $\mathrm{Fe}$ & $4.65 \%$ & $9.40 \%$ & $1.42 \%$ & - & $2.10 \%$ & 4.16 \\
\hline $\mathrm{Mn}$ & 950 & 1300 & 500 & 1200 & 850 & 1039.29 \\
\hline $\mathrm{Ni}$ & 75 & 2000 & 0.5 & 20 & $5-500$ & 19.85 \\
\hline $\mathrm{Pb}$ & 12.5 & 0.1 & 20 & 15 & $2-200$ & 36.80 \\
\hline $\mathrm{Sn}$ & 2 & 0.5 & 3 & 2 & 10 & 57.66 \\
\hline $\mathrm{Zn}$ & 70 & 50 & 40 & 60 & 10300 & 510.75 \\
\hline
\end{tabular}

\section{Silver}

Silver is a chalcophile metal which can occur in nature in the native form, although it is most commonly found as a sulphide or sulphosalt, or as a minor element in a sulphide (Kabata-Pendias and Pendias, 2001).

The element was detected in 151 samples out of the 186 samples analysed. It has a concentration range of $0.02 \mathrm{ppm}$ to $7.36 \mathrm{ppm}$ and a mean value of $2.41 \pm 1.5 \mathrm{ppm}$ (Table 1). This mean value is relatively high when compared with the average abundance of $\mathrm{Ag}$ in soil, ultramafic rocks and granite which are $0.1 \mathrm{ppm}, 0.06 \mathrm{ppm}$ and 0.04 ppm, respectively (Table 2). The location point symbol map (Fig. 3A) shows an even distribution of $\mathrm{Ag}$ over the study area without indicating lithologic influence. However, with a threshold value of $5.41 \mathrm{ppm}$, there are seven anomalous values of between $5.63 \mathrm{ppm}$ and $7.36 \mathrm{ppm}$ forming a NE - SW trend at the southeastern part of the area where pegmatite and granite gneiss are the underlying rocks. Apart from these, there are a few relatively high values (3.61 - 5.42) ppm scattered over the area with a cluster also around the southeastern portion, in an area underlain by pegmatite and pegmatitised schists. 


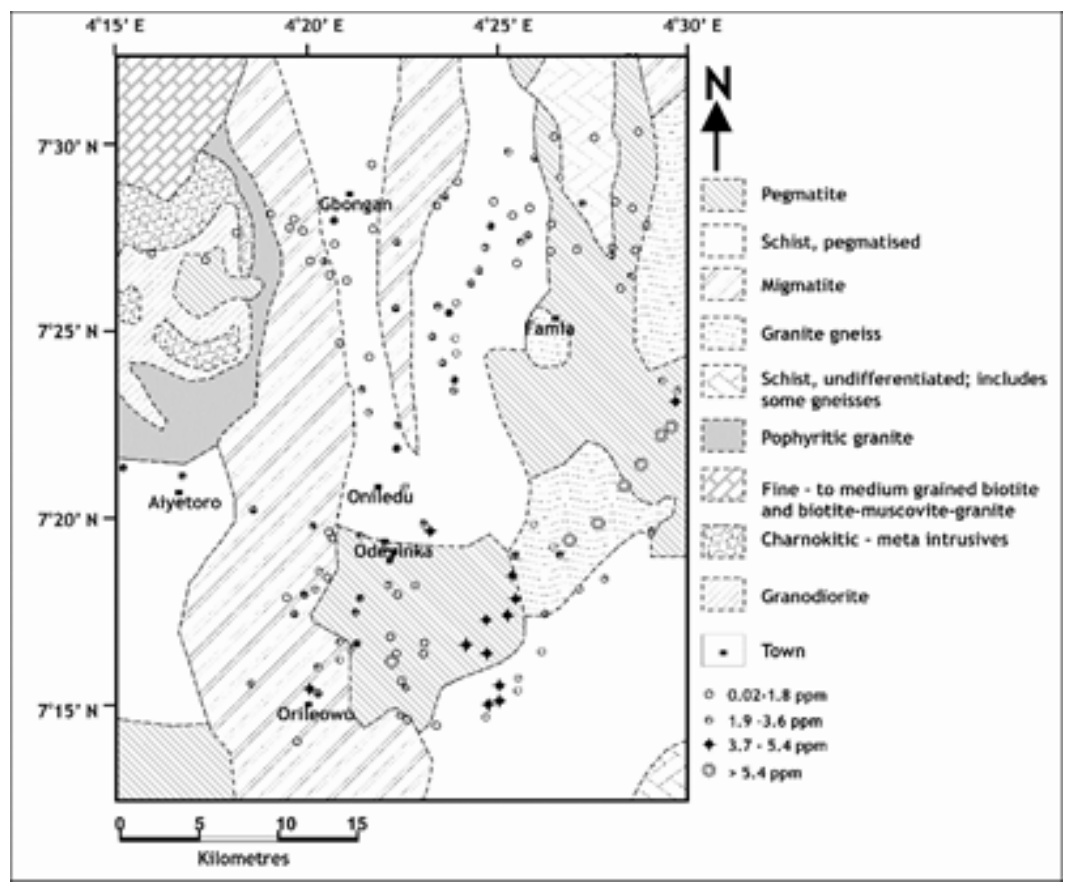

Figure 3A: Location Point Symbol Map of Silver Distribution in Soils of Gbongan-Odeyinka-Orileowu Area.

Since the mean value of silver (2.41 ppm) in soils of the study area is greater than its average abundance in soil and the rocks underlying the area (Table 2), the abundance of silver in this area may be considered high. Consequently, the anomalous values of silver in the area are significant and may be related to the occurrence of primary sulphide mineralization probably in quartz veins occurring within the rocks of the area.

\section{Arsenic}

Arsenic is a chalcophile element which shows strong coherence with Au in practically all types of Au deposits, except the Witwatersrand (KabataPendias and Pendias, 2001). It can be found in minor amount in sphalerite and trace in pyrite while its most abundant ore mineral is arsenopyrite (Plant et al., 2001 and Alexakis, 2008). Arsenic was detected in 180 samples (Table 1). It has a very wide concentration range of $6.4 \mathrm{ppb}$ to $5795.2 \mathrm{ppb}$ with a mean value of $1056.4 \pm 992.72$ ppb and coefficient of variation of $94 \%$. The threshold value for arsenic in this area is 3041.9 ppb, thus there are eight anomalous sites scattered around the north central and the south central portions, in areas underlain by pegmatitised schists and pegmatite, respectively, as shown by the location point symbol map (Fig. 3B). Apart from this, one anomalous value occurs to the western portion where the underlying rock is pegmatitised schists and there are a number of fairly high values scattered all over the area. It is noteworthy that the portions underlain by migmatite in the study area record very low concentration of As except in few places where this rock has contact with pegmatitised schists.

When the mean value of arsenic in this area, which is $1056.4 \mathrm{ppb}$, is compared with the average abundance of As in soil and the earth crust which are $1000-50,000 \mathrm{ppb}$ and $1800 \mathrm{ppb}$ respectively (Table 2), the abundance of arsenic in the study area is low. Consequently, the few anomalous values recorded are insignificant and may not be related to occurrence of As deposit, rather they may indicate the presence of some sulphide minerals in which arsenic is present in trace amounts. Elueze (1977) reported that the areas around Itagumodi and between Iyere and Amuta in Ife-Ilesa Schist Belt are characterized by relatively high density of anomalous arsenic values. He inferred that this is related to the occurrence of sulphide bearing amphibolites which occur in the area. Adesiyan et al. (2014) also reported the common pathfinder for gold (Arsenic) is not associated with the precious metal in the study area and the weak correlation between As and Au buttress the fact that As could not serve as a pathfinder element for Au in the locality. 


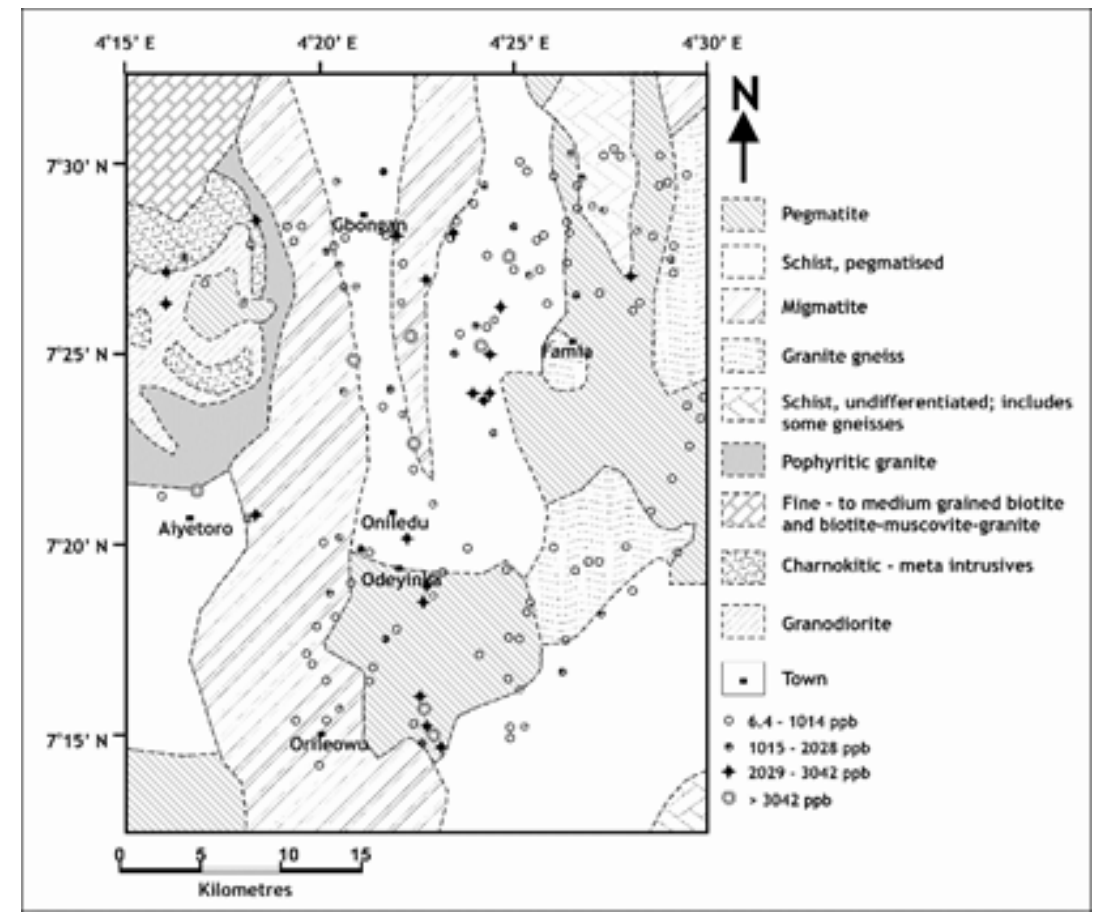

Figure 3B: Location Point Symbol Map of Arsenic Distribution in Soils of Gbongan OdeyinkaOrileown Area.

\section{Gold}

Gold $(\mathrm{Au})$ is a precious metal which commonly occurs in the native form. It also associates with $\mathrm{Ag}, \mathrm{As}, \mathrm{Sb}, \mathrm{Hg}, \mathrm{Se}$, and $\mathrm{Te}$ in precious metal deposits and with $\mathrm{Fe}, \mathrm{Zn}$ and $\mathrm{Cu}$ in many sulphide deposits (Kabata-Pendias and Pendias, 2001; Swiecki, 2005).

Au was detected in 154 out of the 186 samples analysed. Its concentration range is from 0.17 $\mathrm{ppb}$ to $162.4 \mathrm{ppb}$ and it has a mean value of 18.4 $\mathrm{ppb}$. The threshold value is $67.7 \mathrm{ppb}$ and given this value there are only six anomalous values scattered in the northeastern, north central, south central and western portions of the area, which are underlain by undifferentiated schists, pegmatitised schist, pegmatite and undifferentiated gneiss and migmatite (Fig. 3C). Also, there are a few other fairly high values sandwiched between the anomalous and low values in the same area.

A comparison of the mean value of $\mathrm{Au}(18.4 \mathrm{ppb})$ in the soil of the study area with its average abundance in some earth materials including soil (Table 2), suggests that the Au concentration in the anomalous sites of the area is relatively high and is considered significant. This might indicate the presence of primary gold mineralization around these locations, which may occur within quartz veins or as disseminations within some rocks, particularly the schists. Woakes and Bafor (1983) have reported that regionally, primary gold deposits are associated with some Schist Belts (example, Ilesa, Maru, Anka and Kushaka) and that they are often spatially related to amphibolites and regional NE-SW to N-S fault or shear zones, with no specific relationship to Older Granites or BIF. Wright et al. (1985) noted that the primary gold of the Nigerian Basement Complex occurs in form of veins, lenses, stringers, reefs and similar bodies in quartz and quartz-feldspar-tourmaline rocks. Moreover, Oyinloye (1997) reported that the quartz veins which host the Iperindo primary gold deposits are pure massive quartz, occupying fractures in the host biotite granite gneiss where they form a stock work structure. According to him, the quartz veins contain gold, sulphides, Kfeldspar and minor chlorites. Adesiyan and Adekoya (2008) and Adesiyan et al. (2014) established that gold occur in this study area and is hosted by schists and granite gneiss. 


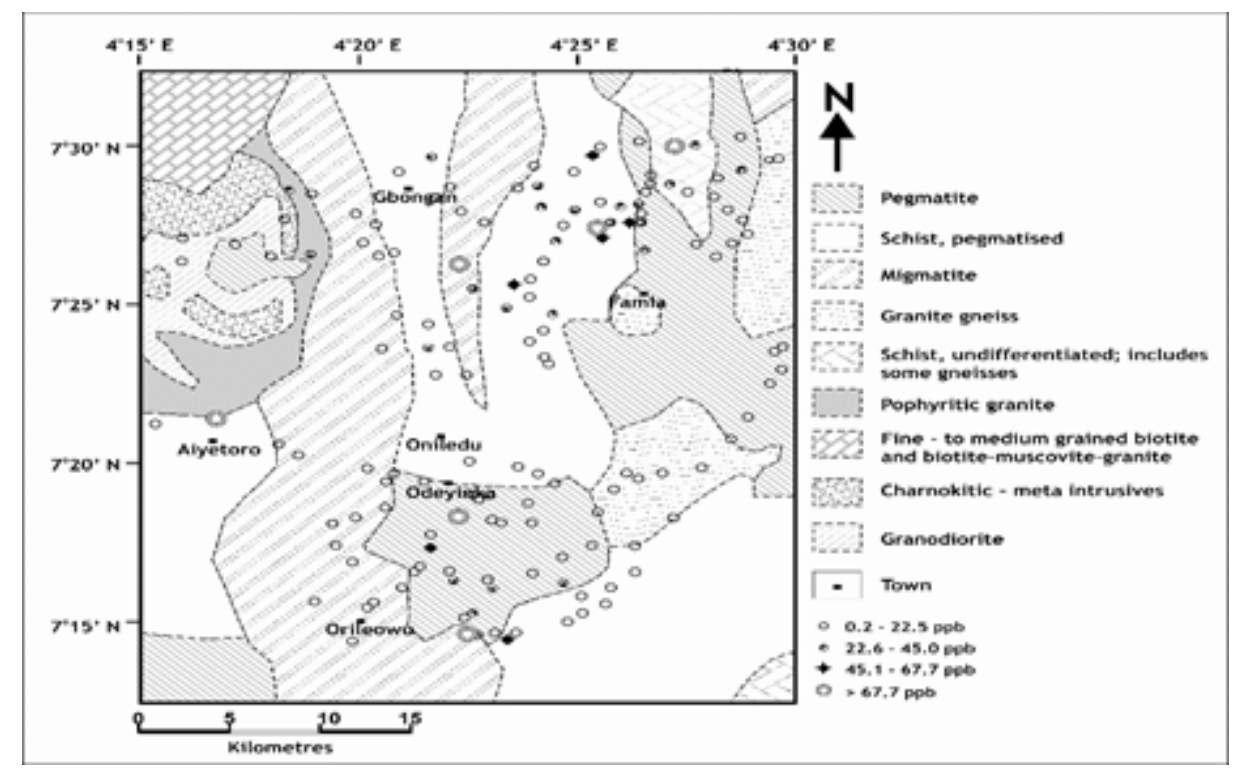

Figure 3C: Location Point Symbol Map of Gold Distribution in Soils of Gbongan-Odeyinka-Orileowu Area.

\section{Cadmium (Cd)}

Cadmium is a chalcophile element which shows an almost universal association with $\mathrm{Zn}$ (KabataPendias and Pendias, 2001). The main Cd mineral is greenockite $(\mathrm{CdS})$ but $\mathrm{Cd}$ also occur in some other minerals notably sphalerite, galena, boulangerite and bournonite. The highest concentration of $\mathrm{Cd}$ is found in sphalerite (Smith, 1999).

Cadmium is widely distributed in the study area as it was detected in 185 out of the 186 samples analysed. It has a concentration range of $0.3 \mathrm{ppb}$ to $404.3 \mathrm{ppb}$ and a mean value of $50.9 \mathrm{ppb}$. The threshold value of $\mathrm{Cd}$ is $182.4 \mathrm{ppb}$ and consequently, there are twelve anomalous $\mathrm{Cd}$ values as seen in its location point symbol map (Fig. 3D). Apart from these, there are a few other fairly high values (121.7 ppb to $182.4 \mathrm{ppb}$ ) and together with the anomalous values they concentrate at the north-eastern and south-central portions of the study area, in parts underlain by schists and pegmatite. Only one anomalous value each occurs in the northwestern and western portions of the area underlain by migmatite.

When the mean value of $\mathrm{Cd}(50.9 \mathrm{ppb})$ in this area is compared with the average abundance of $\mathrm{Cd}$ in some earth materials, which include soil (Table 2), it was observed that the relative abundance of $\mathrm{Cd}$ in the area is low. Thus, the few anomalous concentrations are insignificant and may not be connected with $\mathrm{Cd}$ mineralization but rather serve as a pointer to the occurrence of sulphides and possibly vein-type Au mineralization in which the $\mathrm{Cd}$ occurs as traces in minerals like galena. According to Adesiyan et al. (2014), gold bearing quartz veins typically carry some sulphides; galena and pyrite being the most common.

Moreover, the location point symbol map of $\mathrm{Cd}$ in the study area (Fig. 3D) has a fairly similar feature to that of $\mathrm{Au}$ (Fig. 3C). This reflects the possibility of an association between $\mathrm{Cd}$ and $\mathrm{Au}$ in this area, similar to what Ajayi (1988), Elueze (1977) and Oyinloye (1997) reported in the Ife-Ilesha area. According to them, the spatial relationship of anomalous $\mathrm{Cd}$ areas with those of known gold deposits in Ife-Ilesha area could make Cd a possible pathfinder element for $\mathrm{Au}$ in the area. The occurrence of Au with $\mathrm{Cd}$ in factor of the Rmode varimax rotated factor analysis suggested that $\mathrm{Cd}$ could be a possible pathfinder for gold in the study area (Adesiyan et al., 2014). 


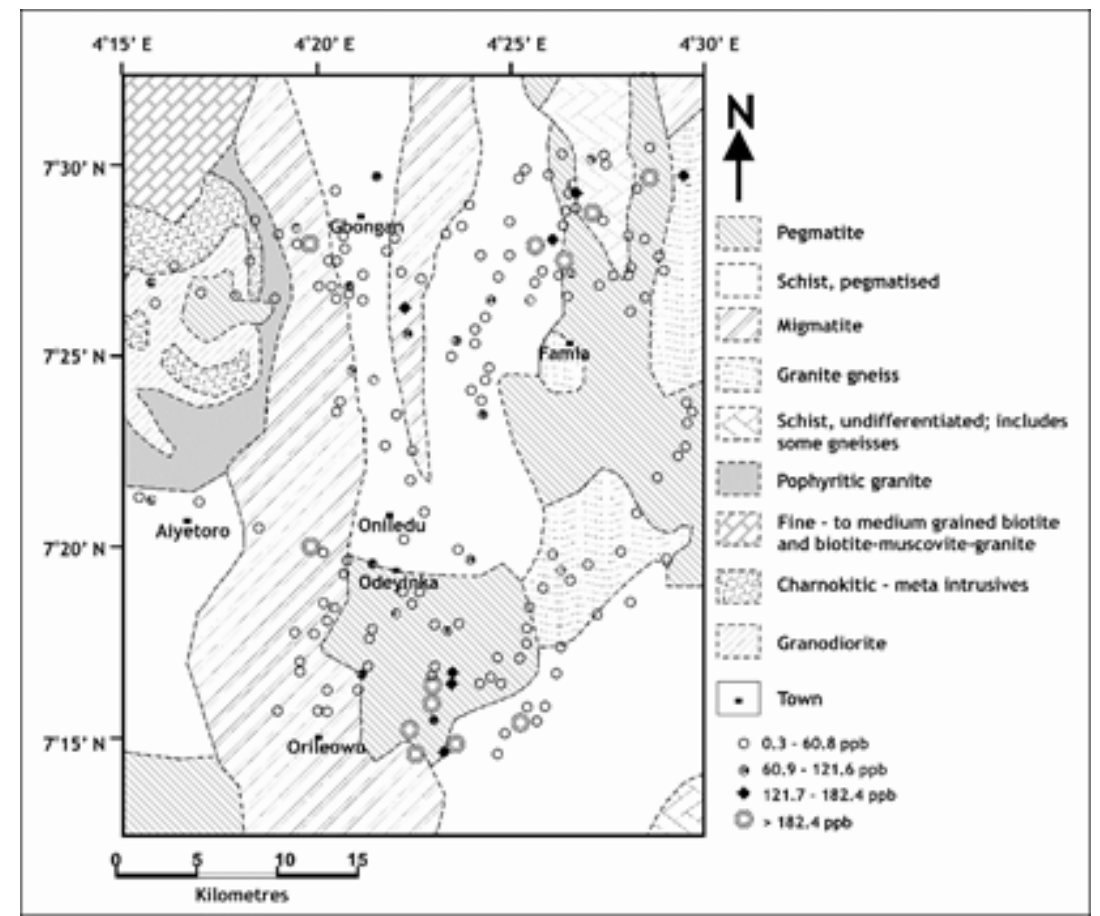

Figure 3D: Location Point Symbol Map of Cadmium Distribution in Soils of Gbongan-OdeyinkaOrileown Area.

\section{Cobalt}

Cobalt is mainly a chalcophile element and it associates with $\mathrm{Mg}$ and $\mathrm{Ni}$ in mafic and ultramafic rocks (Kabata-Pendias and Pendias, 2001). It is present in trace amounts in some major rock forming minerals such as olivine, amphibole, pyroxene and biotite as well as in magnetite. In hydrothermal deposits, cobalt readily enters as an isomorphous impurity of $\mathrm{Fe}$ in sulphide and arsenide ores and for this reason pyrite and arsenopyrite often contain $\mathrm{Co}$ in workable concentrations (Plant et al., 2001).

The distribution of cobalt in the study area is very wide as it was detected in all the samples analysed. It shows a wide variation of concentration with values ranging between $2.1 \mathrm{ppm}$ and $352 \mathrm{ppm}$ and it has a mean value of $44 \mathrm{ppm}$. The threshold value of Co is $148.3 \mathrm{ppm}$ and thus there are only nine anomalous values, some of which are scattered around the north central portion of the study area while three of them form a N-S trend at the southern portion (Fig.3E). Apart from these anomalous values, there are other fairly high values (98.9 ppm - $148 \mathrm{ppm}$ ) which occur around the anomalous sites, with only one in the northwestern portion of the area. Both the anomalous values and the fairly high concentration values of $\mathrm{Co}$ occur in portions mostly underlain by pegmatite and pegmatitised schists, and to a lesser extent migmatite and granodiorite.

When we compare the mean value of Co in the study area $(44 \mathrm{ppm})$ with the average abundance of Co in soil and mafic/ultramafic rocks, which are $40 \mathrm{ppm}$ and $150 \mathrm{ppm}$ respectively (Table 2), the abundance of Co in the area is low. Thus, the few anomalous values are insignificant and probably result from co-precipitation of Co with Mn oxide. This is observable with the striking similarity in the distribution patterns of Co and $\mathrm{Mn}$, as revealed by the elements distribution maps. The cobalt might have its origin in some underlying mafic/ultramafic rocks and or sulphide bearing quartz veins. 


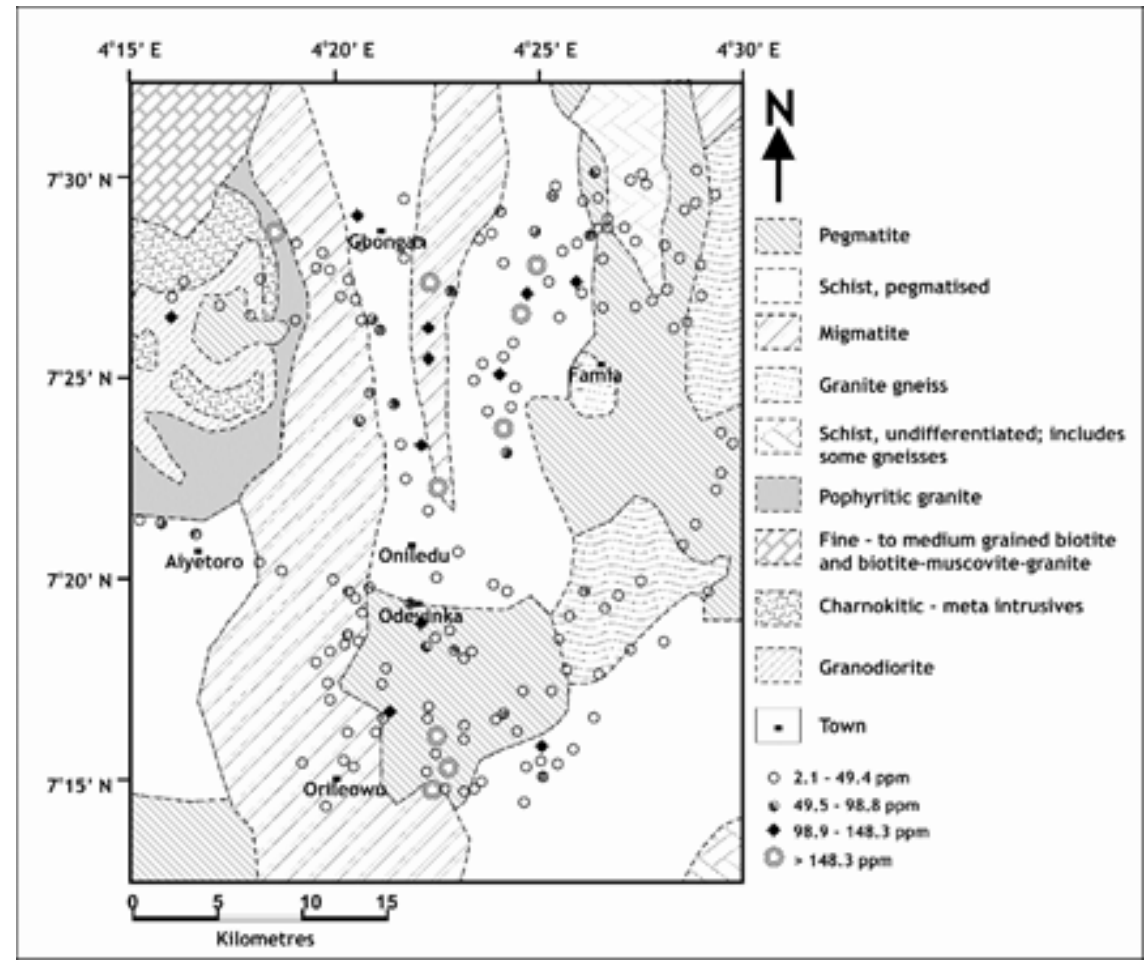

Figure 3E: Location Point Symbol Map of Cobalt Distribution in Soils of Gbongan-OdeyinkaOrileown Area.

\section{Chromium}

Chromium is a lithophile element, which possesses a strong association with $\mathrm{Ni}$ and $\mathrm{Mg}$ in ultramafic rocks. $\mathrm{Cr}^{+3}$ have identical size with $\mathrm{Fe}^{+3}$ and $\mathrm{Al}^{+3}$ and will readily concentrate in minerals, which will accommodate these trivalent ions, such as pyroxene (Mc Lennan and Taylor, 1991). However, $\mathrm{Cr}$ occurs in varying quantities in other rock-forming minerals such as olivine, amphibole, biotite, sphene, apatite, muscovite and tourmaline (Kabata-Pendias and Pendias, 2001).

Chromium was detected in 176 out of the 186 samples analysed. The elemental contents in the samples show a wide variation, with values ranging between $0.3 \mathrm{ppm}$ and $246.7 \mathrm{ppm}$. Cr has a mean value of $29.4 \mathrm{ppm}$ and a threshold value of 103.1 ppm. With this threshold value, there are only eight anomalous values scattered in the northern half of the area in parts underlain largely by pegmatitised schists and to a lesser extent by charnockitic meta-intrusives and migmatites.
This can be seen in the location point symbol map of $\mathrm{Cr}$ in the study area (Fig. 3F). There are also a few other fairly high values occurring without any discernable pattern. Generally, low values of $\mathrm{Cr}$ in this area are associated with pegmatite except in areas where the rock is in contact with pegmatitised schists.

When the mean value of $\mathrm{Cr}$ in the study area (29.4 $\mathrm{ppm}$ ) is compared with the average abundance of the element in soil which is $5-1000$ ppm (Table 2), the abundance of $\mathrm{Cr}$ in the study area is very low. The few anomalous concentrations of $\mathrm{Cr}$ in the area are therefore insignificant and may result from co-precipitation of the element with Fe - Mn oxides. This is reflected in the fairly close similarity in the distribution patterns of $\mathrm{Cr}, \mathrm{Ni}, \mathrm{Pb}, \mathrm{Fe}, \mathrm{Mn}$ and $\mathrm{Co}$ as shown by their distribution maps. The primary source of $\mathrm{Cr}$ in this area may be the mafic or ultramafic rocks present in the underlying bedrock. 


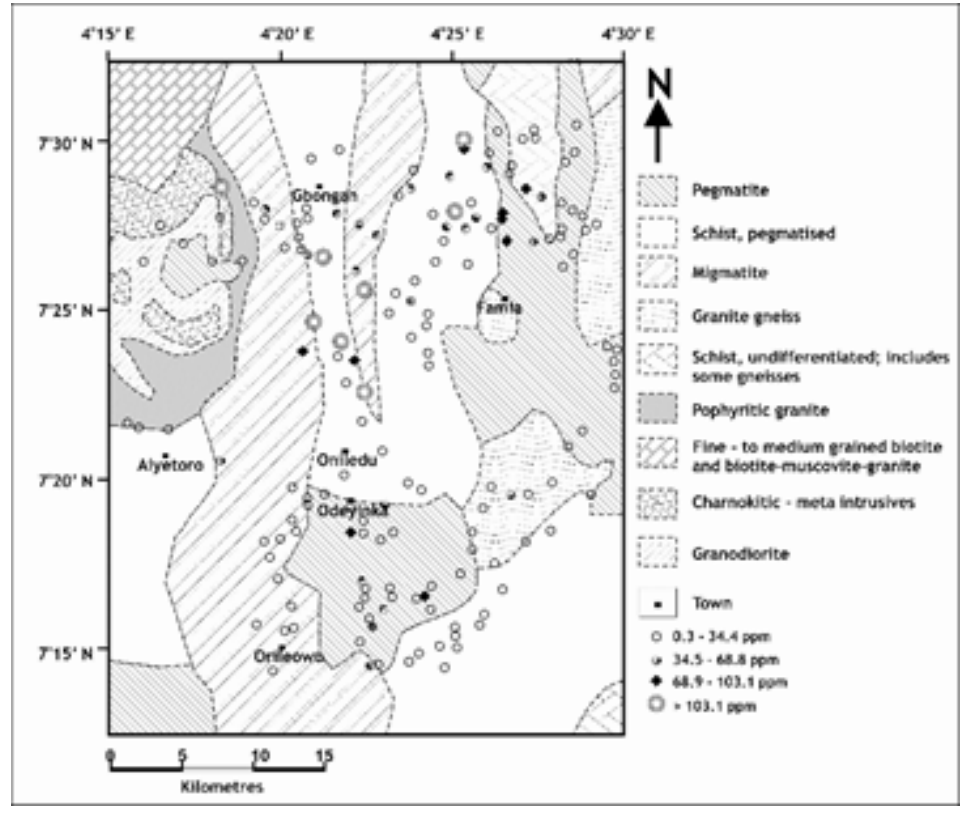

Figure 3F: Location Point Symbol Map of Chromium Distribution in Soils of Gbongan-OdeyinkaOrileown Area.

\section{Copper}

Copper is a chalcophile element which sometimes occurs in the native form. It is found in most rock forming minerals, since $\mathrm{Cu}$ will enter plagioclase and apatite, substituting for $\mathrm{Na}^{+}$and $\mathrm{Ca}^{+}$during magma crystallization. It will also enter minerals containing $\mathrm{Fe}^{2+}$. Therefore, most ferromagnesian minerals will house copper. However, it prefers the sulphide phase to the silicate phase (Reimann and de Caritat, 1998). Cu has intermediate mobility, which is controlled by adsorption to $\mathrm{Fe}-\mathrm{Mn}$ oxides and organic matter and precipitation by hydrolysis at $\mathrm{pH}>5.0$ (KabataPendias and Pendias, 2001).

The location point symbol map showing distribution of copper in the study area (Fig. 3G) revealed that the element is widely distributed in the area. It was detected in 185 out of the 186 samples analysed, and its concentration ranges from 2.4 to $102 \mathrm{ppm}$. This is consistent with the work of Ajayi (1988) who obtained a concentration range of between 6 and $196 \mathrm{ppm}$ for $\mathrm{Cu}$ in the soils of part of Ife - Ilesha Schist
Belt. The mean value of $\mathrm{Cu}$ is $25.1 \mathrm{ppm}$ and the threshold value is $58.9 \mathrm{ppm}$. With this threshold, there are only six anomalous values, apart from a few other relatively high values of between 39.3 and $58.9 \mathrm{ppm}$. The anomalous concentrations together with the relatively high values of $\mathrm{Cu}$ occur at the north central and south central portions of the area in parts underlain by pegmatite and pegmatitised schists and, to a lesser extent, migmatite.

Comparing the mean value of $\mathrm{Cu}(25.1 \mathrm{ppm})$ in this area with the average abundance of copper in soil $(2-100 \mathrm{ppm})$ (Table 2), the abundance of $\mathrm{Cu}$ in the area can be said to low. In this connection, the few anomalous values are insignificant and may not be related to occurrence of $\mathrm{Cu}$ ore. However, since most rock forming minerals will house copper, occurrence of the anomalous concentrations may be a pointer to the coprecipitation of $\mathrm{Cu}$ with $\mathrm{Fe}-\mathrm{Mn}$ oxides in the area underlain by heterogeneous rock types. Also, the association of $\mathrm{Cu}$ with the inferred sulphide bearing quartz veins may not be ruled out. 


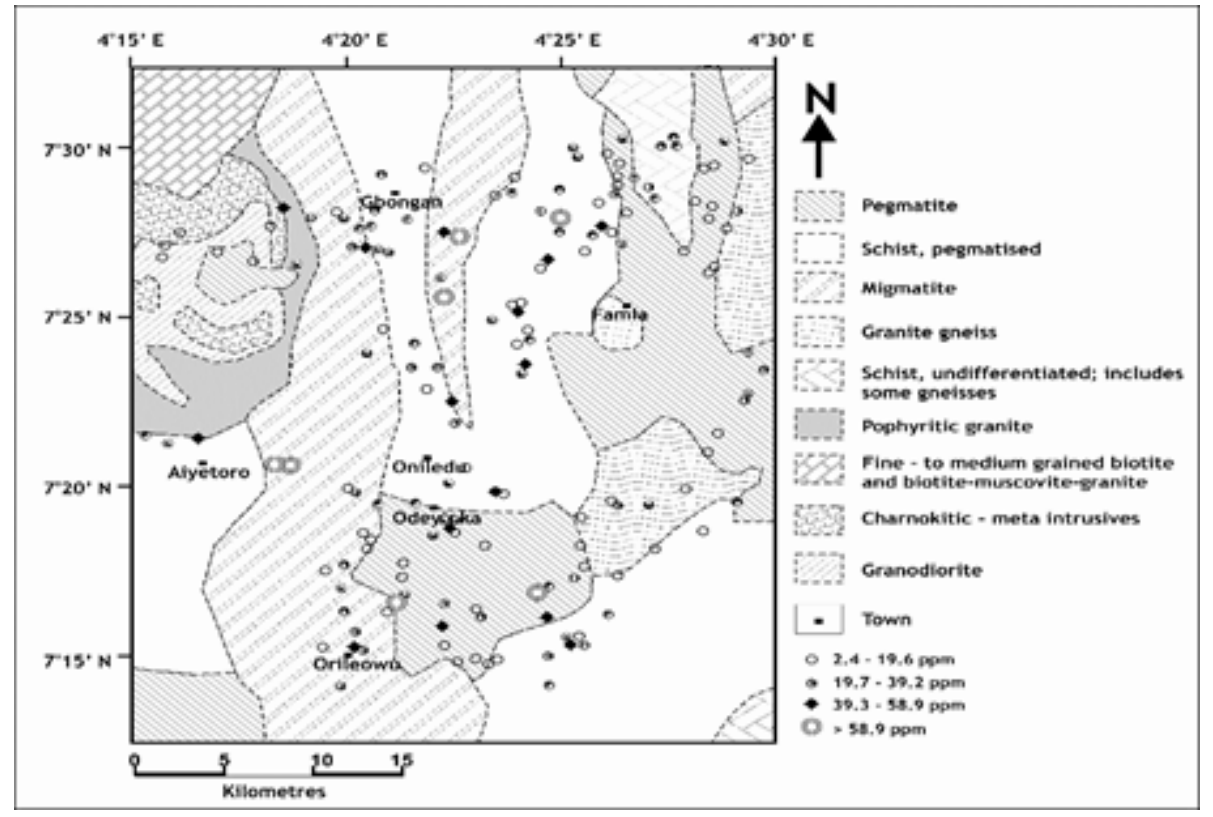

Figure 3G: Location Point Symbol Map of Copper Distribution in Soils of Gbongan-OdeyinkaOrileowu Area.

\section{Iron}

Iron is a siderophile element, which occurs in deposits of different genetic types, with sedimentary and metamorphic deposits being the most important industrially (Kabata-Pendias and Pendias, 2001). Iron, together with $\mathrm{Mg}$, plays an important role in the formation of a number of rock forming silicates like olivine, pyroxene, amphibole and mica, although it's major ore minerals are hematite and magnetite.

It is important to note that in soils overlying sulphide ores and in the beds of streams draining them, some of the ore metals are co-precipitated with Fe-oxides. Thus, the metal content of the resulting limonitic material may be a useful ore guide (Kabata-Pendias and Pendias, 2001).

Iron has a wide distribution in the study area, as it can be seen in its location point symbol map (Fig. $3 \mathrm{H})$. It was detected in all the samples analysed with a concentration range of $0.8 \%-10.5 \%$ and a mean value of $4.2 \%$. The coefficient of variation is $46 \%$ and there is a threshold value of $8.0 \%$. With this value, there are only six anomalous concentrations of $\mathrm{Fe}$ in the study area, although we have a number of relatively high values. The anomalous values and the relatively high values together have a uniform distribution over the area without showing any lithologic influence. However, there are three clusters of high values in the area, with one around the central portion and the remaining two at the south central and southwestern portions of the area.

When the mean value of extractable $\mathrm{Fe}$ in the study area $(4.2 \%)$ is compared with the average abundance of $\mathrm{Fe}$ in soil $(2.1 \%)$, the earth crust $(4.7 \%)$ and mafic/ultramafic rocks (9.4\%) (Table $2)$, the abundance of $\mathrm{Fe}$ in the area is relatively moderate. Therefore, the few anomalous concentrations are insignificant and may not be attributed to $\mathrm{Fe}$ mineralization in the area but rather to the precipitation of $\mathrm{Fe}$ as oxides in the soils. 


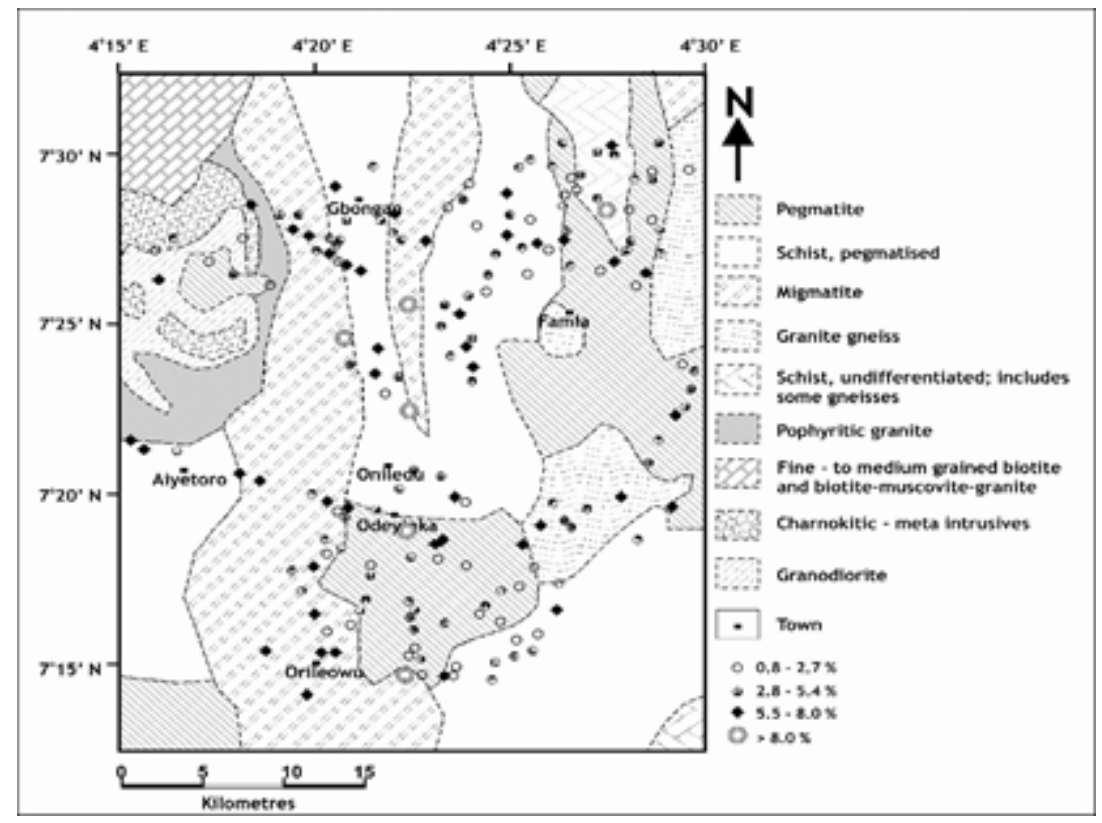

Figure 3H: Location Point Symbol Map of Iron Distribution in Soils of Gbongan-OdeyinkaOrileown Area.

\section{Manganese}

Manganese is a lithophile element which is associated mostly with mafic igneous rocks; a common associate of $\mathrm{Mg}$ and $\mathrm{Fe}$ in silicates (Kabata-Pendias and Pendias, 2001). Chemically, Mn stands closest to iron and it forms more than a hundred minerals, only few of which are widespread and rich. The principal ore mineral of $\mathrm{Mn}$ is pyrolusite, although it occurs in most mafic minerals. Manganese has intermediate to low mobility, except in the acid, reducing environment of organic swamps and bogs where it can move very readily (Kabata-Pendias and Pendias, 2001). Like Fe, the element $\mathrm{Mn}$ is extremely important in geochemical exploration because of the very large number of trace elements that may co-precipitate with or adsorb on Mn oxides (Reimann and de Caritat, 1998).

The distribution of $\mathrm{Mn}$ in soils of the study area is very wide as it was detected in all the samples analysed (Fig. 3I). Its concentration shows a wide variation with values ranging from $13.0 \mathrm{ppm}$ to $9460.6 \mathrm{ppm}$. The mean concentration for $\mathrm{Mn}$ is $1039.3 \mathrm{ppm}$ and it has a threshold value of 4118.4 ppm. With this threshold, there are only nine anomalous values which together with the other relatively high values are randomly distributed over the area. These anomalous and relatively high concentrations are distributed without much lithologic control although there seems to be preference for high concentrations in the soils in areas underlain by pegmatitised schists and pegmatites.

When the mean value of $\mathrm{Mn}$ in the study area (1039.3 ppm) is compared with its average abundance in soil (850 ppm), mafic/ultramafic rocks (1300 ppm) and granodiorite (1200 ppm) (Table 2), the abundance of $\mathrm{Mn}$ in the area is somewhat moderate and thus insignificant. The few anomalous values and the other relatively high values may therefore be related to the precipitation of $\mathrm{Mn}$ as oxides in soils possibly derived from mafic $/ \mathrm{Mg}$ and $\mathrm{Fe}$ rich silicate rocks in the study area. Ajayi (1988) obtained a concentration range of $80-4480 \mathrm{ppm}$ for Mn in soils of part of Ife Ilesa Schist Belt.

Moreover, there is a fair similarity in the distribution patterns of $\mathrm{Mn}$ and $\mathrm{Fe}$ in the study area, as revealed by their location point symbol maps. This is probably as a result of the scavenging effects of oxides of both metals on the same set of elements in the area, notably, Co and $\mathrm{Pb}$. A closer look at the distribution maps of $\mathrm{Co}$ and $\mathrm{Pb}$ shows a striking similarity, which also suggests a similar distribution pattern for these elements. On the whole one can conclude that the distribution patterns of $\mathrm{Mn}, \mathrm{Fe}, \mathrm{Co}$ and $\mathrm{Pb}$ in the study area are similar. 


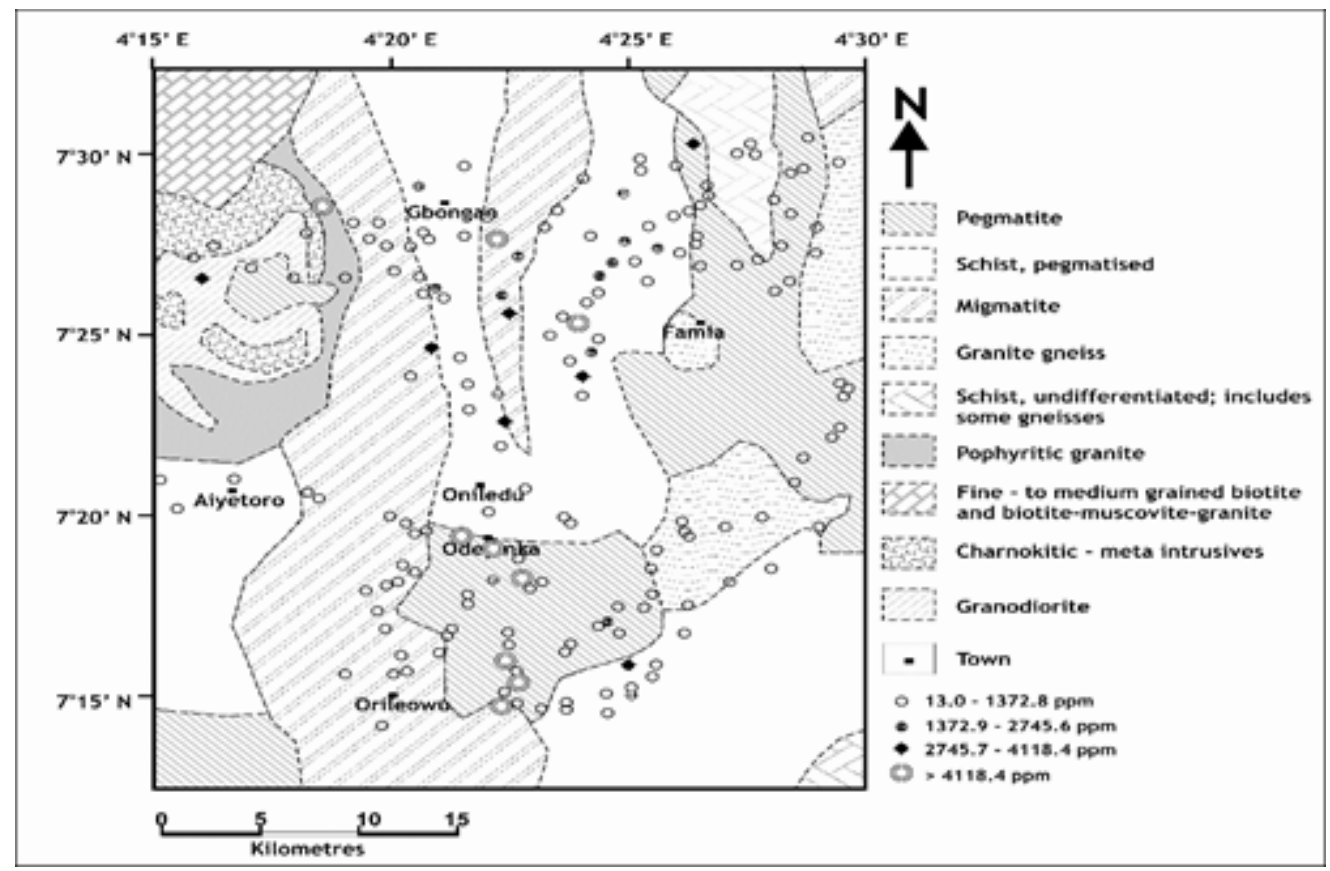

Figure 3I: Location Point Symbol Map of Manganese Distribution in Soils of Gbongan-OdeyinkaOrileown Area.

\section{Nickel}

Nickel is a siderophile and to a lesser degree, chalcophile element, which is chemically related to cobalt. It normally associates with $\mathrm{Mg}$ and $\mathrm{Co}$ in ultramafic and mafic rocks and with $\mathrm{Co}, \mathrm{Cu}$ and $\mathrm{Pt}$ in sulphide deposits. It is found in rock forming minerals such as olivine, pyroxene, biotite and plagioclase and in magnetite. Mobility of $\mathrm{Ni}$ is relatively low and it is limited by co-precipitation with limonite and hydrolysis, where $\mathrm{pH}$ is greater than 6.5 (Kabata-Pendias and Pendias, 2001). The tendency of $\mathrm{Ni}$ to hydrolyse at $\mathrm{pH}$ above 6.5 is reflected in this work, as most of the samples with anomalous values of $\mathrm{Ni}$ have $\mathrm{pH}$ above 6.5.

Nickel was detected in 174 out of the 186 samples analysed. Its distribution in the study areas is relatively wide (Fig. 3J) and it has a concentration range of $0.62 \mathrm{ppm}$ to $126.6 \mathrm{ppm}$ with a mean value of $19.9 \mathrm{ppm}$ and coefficient of variation of $75 \%$. This is consistent with the work of Ajayi (1988) who obtained a Ni concentration in the range of 6 to $100 \mathrm{ppm}$ for soils from some parts of Ife-Ilesa Schist Belt. The threshold value of $\mathrm{Ni}$ in the study area is $49.8 \mathrm{ppm}$ and based on this value, there are only seven anomalous $\mathrm{Ni}$ values. A part from these, there are a few other relatively high values, which together with the anomalous values are distributed randomly at the north central portion of the area with only three occurring at the south central portion. The anomalous values and the relatively high values concentrate in area underlain mostly by pegmatitised schist at the north central part, while at the south central portion a few are found on soils overlying pegmatite and pegmatitised schists.

A comparison of the mean value of nickel (19.9 ppm) with the average abundance of nickel in soil $(5-500 \mathrm{ppm})$ (Table 2) reveals that the abundance of $\mathrm{Ni}$ in the study area is low. Hence, the few anomalous values are insignificant and may not be related to any $\mathrm{Ni}$ mineralisation in the area. Rather, they may be attributed to the coprecipitation of $\mathrm{Ni}$ with $\mathrm{Fe}$-oxide in the vicinity of mafic/ultramafic suites, more so that the distribution of $\mathrm{Ni}$ in the study area, as revealed by its distribution map (Fig. 3J) is similar to those of $\mathrm{Co}, \mathrm{Cr}, \mathrm{Fe}, \mathrm{Mn}$ and Pb. Babafemi (1983) reported the occurrence of amphibolites and talctremolite-actinolite schists in Akinlalu, a part of the study area. Adesiyan (2010) concluded that, since $\mathrm{Ni}^{2+}$ substitutes readily for $\mathrm{Mg}^{2+}$ and $\mathrm{Fe}^{2+}$, a high background concentration of the element in amphibolite must be expected. He obtained relatively high values of $\mathrm{Ni}(>100 \mathrm{ppm})$ from some stream sediments predominantly within amphibolite zone of Ife-Ilesa Schist Belt. He also 
obtained some isolated high values (>100 ppm) within the micaceous Schist Belt. Similarly, Ajayi (1988) reported that the distribution map of nickel in soils of Ife-Ilesa Schist Belt reveals that the greater percentage of high concentrations falls within the area underlain by amphibolite. Also, Zhai et al. (2003) concluded that the concentrations of heavy metals in Gaborone (capital city of Botswana) rural soils are strongly influenced by the bedrock above which they are found. It is thus possible to infer that the origin of $\mathrm{Ni}$ in the study area is the underlying mafic/ultramafic rocks.

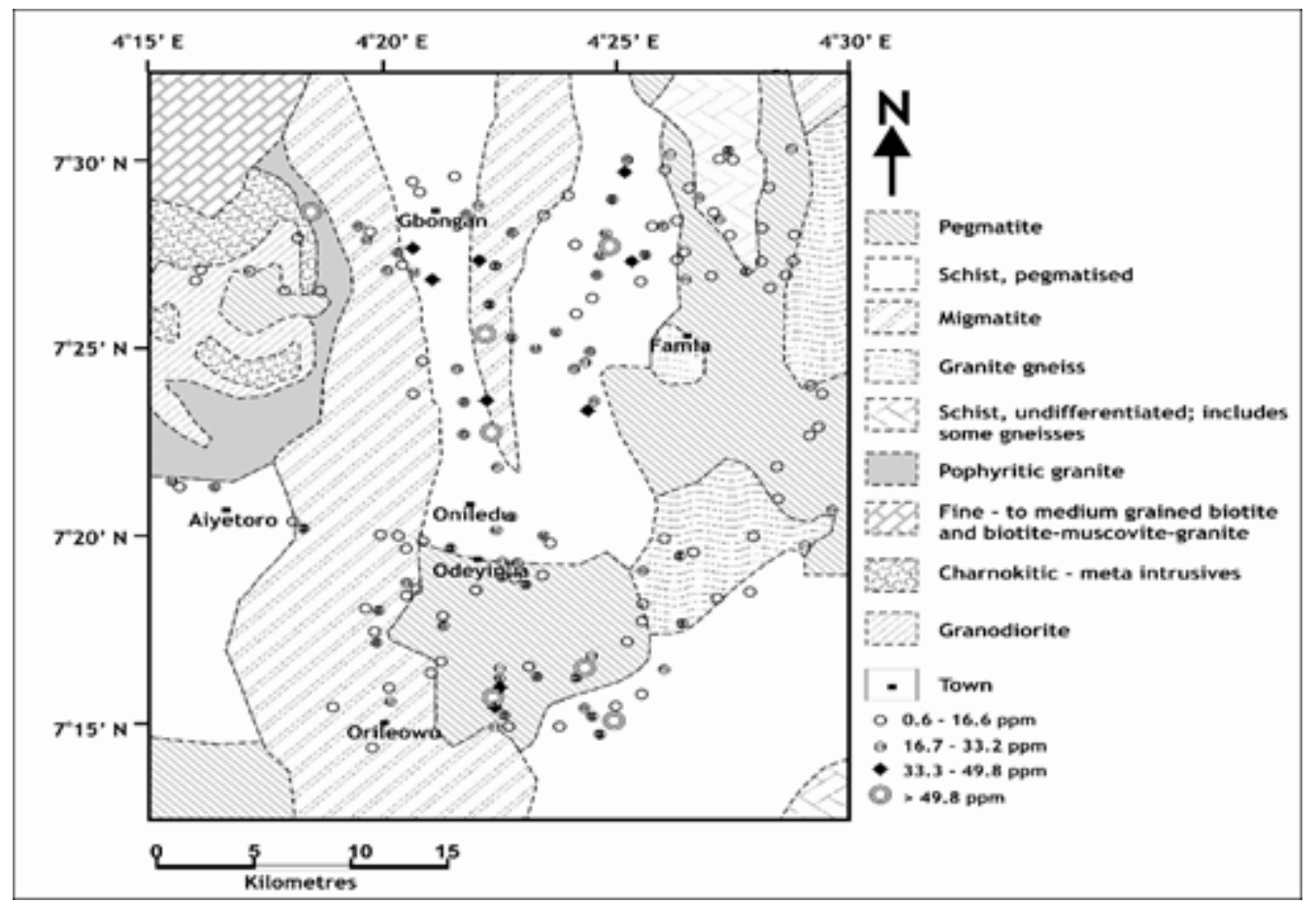

Figure 3J: Location Point Symbol Map of Nickel Distribution in Soils of Gbongan-OdeyinkaOrileowu Area.

\section{Lead}

Lead is a chalcophile element which commonly associates with $\mathrm{Ag}$ in precious metal deposits and with $\mathrm{Fe}, \mathrm{Zn}, \mathrm{Cu}$ and $\mathrm{Sb}$ in many sulphide deposits (Kabata-Pendias and Pendias, 2001). It is more often found $\mathrm{as}^{2+}$ and occurs in trace amounts in major rock forming minerals like amphibole, micas and K-feldspars. Mobility of lead is relatively low as it is restricted by its tendency for adsorption to $\mathrm{Mn}-\mathrm{Fe}$ oxides and insoluble organic matter.

The distribution of $\mathrm{Pb}$ in the study area is very wide as it was detected in 183 out of the 186 samples analysed (Fig. 3K). It has a concentration range of 2.8 to $186.8 \mathrm{ppm}$, with a mean value of $36.8 \mathrm{ppm}$ and coefficient of variation of $76 \%$. The threshold value of lead in this area is $92.8 \mathrm{ppm}$ and thus there are only five anomalous values randomly distributed at the northern half of the area. Apart from these, there are other relatively high values $(61.9-92.8 \mathrm{ppm})$, some of which are also randomly distributed at the northern half, while others are concentrated at the central portion of the southern half of the area. The anomalous values together with the relatively high values at the northern half of the study area occur predominantly in soils overlying pegmatitised schists, with a few in soils developed on other rock types. In contrast, the high values at the southern half of the area are restricted to soils underlain by pegmatite.

When the mean value of $\mathrm{Pb}$ in the study area (36.8 $\mathrm{ppm})$ is compared with its average abundance in soil $(2-200 \mathrm{ppm})$ (Table 2$)$, the abundance of $\mathrm{Pb}$ in this area is rather low and thus insignificant. The few anomalous concentrations may result from accumulation of $\mathrm{Pb}$ in soils of the area due to coprecipitation of the element with $\mathrm{Fe}-\mathrm{Mn}$ oxides 
or from a possible occurrence of sulphide bearing Au quartz veins. Woakes et al. (1987) have reported that gold bearing quartz veins in Nigeria often contain some sulphides, galena and pyrite being the most common. Moreover, the abundance of feldspar in the pegmatites of the study area and mica in the gneisses and migmatite may be a source of the available $\mathrm{Pb}$ that coprecipitates with $\mathrm{Fe}-\mathrm{Mn}$ oxides. The fact that $\mathrm{Pb}$ occurs in trace amounts in major rock forming minerals (Kabata-Pendias and Pendias, 2001) is buttressed by this study which reveals that high $\mathrm{Pb}$ values are likely to be favoured by the high feldspar content of the underlying pegmatite bedrock. This is consistent with the observation of Adesiyan and Adekoya (2008) on the accumulation of $\mathrm{Pb}$ in pegmatite in which it occurs in amazonite feldspar. Also Smith et al. (1996) reported the enrichment of lead in acid igneous rocks.

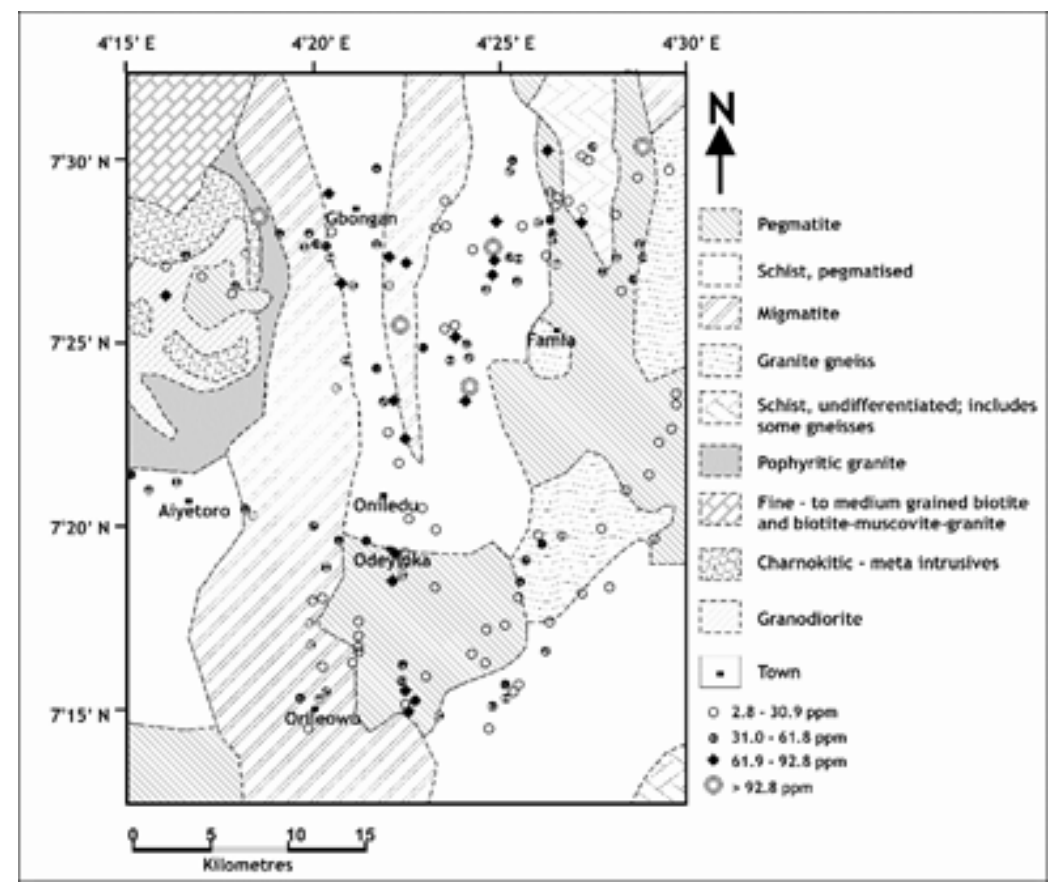

Figure 3K: Location Point Symbol Map of Lead Distribution in Soils of Gbongan-OdeyinkaOrileowu Area.

\section{Tin}

Tin is a siderophile and, to a lesser extent, lithophile element. It commonly associates with $\mathrm{B}, \mathrm{F}, \mathrm{Li}$ and $\mathrm{Rb}$ in late-stage differentiates of granites and with $\mathrm{Be}, \mathrm{Li}, \mathrm{Nb}-\mathrm{Ta}, \mathrm{W}$ and rare earth elements in pegmatites (Kabata-Pendias and Pendias, 2001). The principal ore mineral of $\mathrm{S} n$ is cassiterite $(78.6 \% \mathrm{Sn})$ while the metal is found in trace amounts in some rock forming minerals (e.g. biotite).

Tin does not have a widespread distribution in soils of the study area (Fig.3L). It was detected in only 112 out of the 186 samples analysed and it has a wide concentration range of $0.2 \mathrm{ppm}$ to $171.6 \mathrm{ppm}$ with a mean value of $57.7 \mathrm{ppm}$ and coefficient of variation of $82 \%$. Okunlola (2006) obtained a concentration range of $16-200 \mathrm{ppm}$ and $15-100 \mathrm{ppm}$ for Sn in pegmatites of Ijero Aramoko and Ibadan - Osogbo areas, respectively in SW Nigeria. The threshold value obtained for $\mathrm{Sn}$ in soils of the study area is $152.3 \mathrm{ppm}$. Consequently, there are only three anomalous concentrations, one of which occurs in a portion underlain by pegmatite at the northeastern part of the area, while the other two are at the northwestern and north central portions underlain by porphyritic granite and pegmatitised schists, respectively. Besides these anomalous concentrations there are a number of other relatively high values (101.7 - 152.3 ppm) scattered about the northeastern, northwestern and southwestern portions of the area. In totality, it appears the largest proportion of the high $\mathrm{Sn}$ concentration in soils of this area falls in the western half of the map apparently without much 
lithologic control.

A comparison of the mean value of $\mathrm{Sn}$ in soils of the study area $(57.7 \mathrm{ppm})$ with the average abundance of tin in soil (10.0 ppm) indicates that the abundance of $\mathrm{Sn}$ in the area is comparatively high. Consequently, the anomalous and the relatively high $\mathrm{Sn}$ values may be attributed to primary tin mineralization in the area. The source of the tin is likely to be the pegmatites in the area. Adesiyan et al. (2014) established that $\mathrm{Sn}$ is hosted by pegmatites and pegmatised schists (that is, schists massively invaded by pegmatites) and is contained in the residual soils derived from this underlying rock type. Adesiyan and Adekoya (2003) reported anomalous concentrations of Sn in stream sediments derived from the area underlain by pegmatitised schists and undifferentiated schists in the northern half of the study area. Ako (1980) documented the presence of $\mathrm{Sn}$ in pegmatites of the adjacent area to the study area. Ajayi (1988) reported that cassiterite and columbite together with alluvial gold have been won in Iregun, a village in Ife-Ilesa area. According to him both minerals are derived from the weathered pegmatites intruded into the gneisses, migmatites and schists of the Basement Complex. Owoeye et al. (2015) attributed anomalous tin values recorded (with mean of $80.48 \mathrm{ppm}$ ) in stream sediments of Telemu-Ede area to tin mineralization in areas underlain by pegmatites.

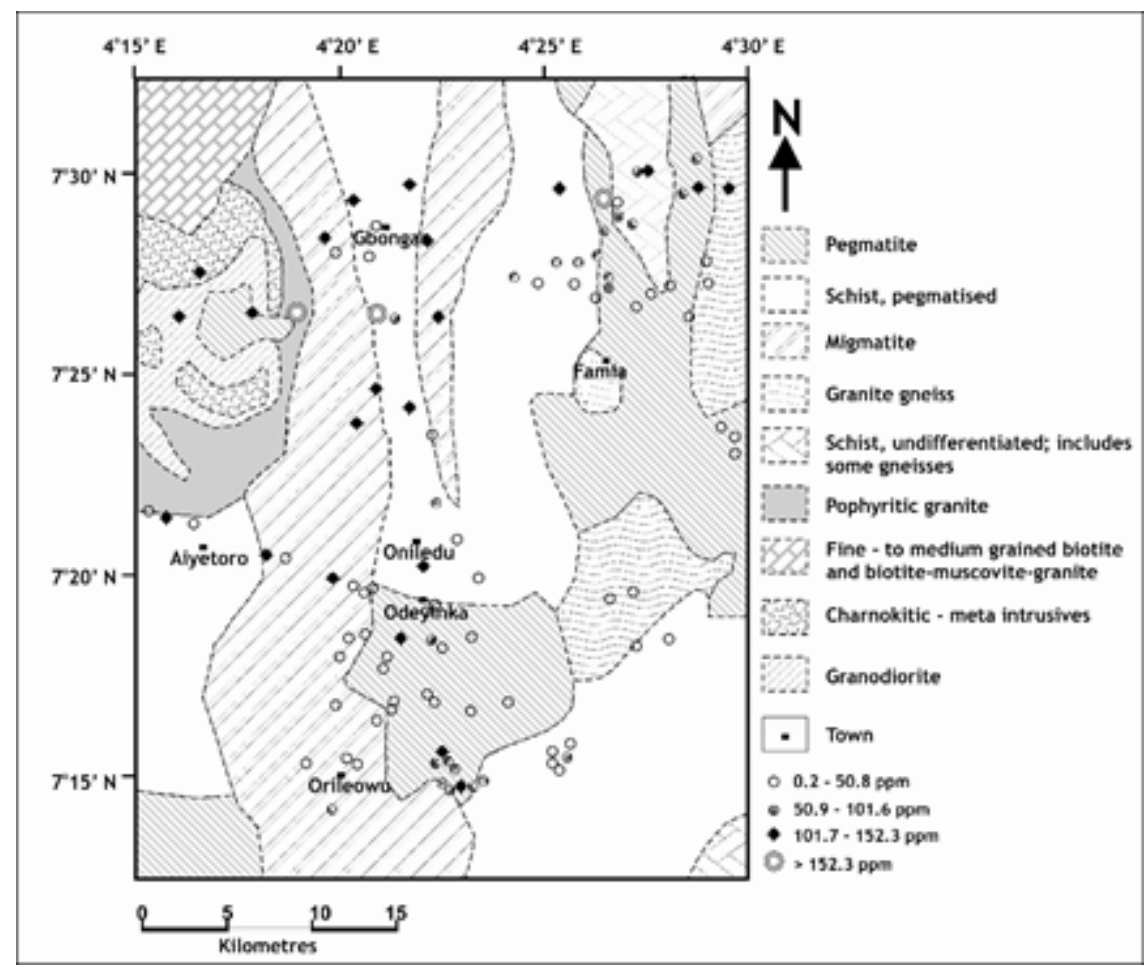

Figure 3L: Location Point Symbol Map of Tin Distribution in Soils of Gbongan-OdeyinkaOrileowu Area.

\section{Zinc}

Zinc is a chalcophile element which associates with $\mathrm{Cu}, \mathrm{Pb}, \mathrm{Ag}, \mathrm{Au}, \mathrm{Sb}, \mathrm{As}$ and $\mathrm{Se}$ in base metal and precious metal deposits. It also associates with $\mathrm{Mg}$ in some silicates, and is found in trace amount in ferromagnesian minerals, plagioclase, epidote, K-feldspar, muscovite and quartz. The primary and major ore mineral of $\mathrm{Zn}$ is sphalerite while its secondary minerals include smithsonite and hemimorphite. The mobility of $\mathrm{Zn}$ is moderately high but it is limited by its tendency to be adsorbed by $\mathrm{MnO}_{2}$ and insoluble organic matter (Mihaljevic, 1999b).

The distribution of $\mathrm{Zn}$ in soils of the study area as shown by the location point symbol map (Fig. 3M) is very wide as it was detected in all the 186 samples analysed. It has a wide concentration range of $3.6 \mathrm{ppm}-7085.4 \mathrm{ppm}$, with a mean value of $510.8 \mathrm{ppm}$ and coefficient of variation of 176 $\%$. The threshold value for $\mathrm{Zn}$ is $2305.7 \mathrm{ppm}$ and as such there are only seven anomalous values, five 
of which are randomly distributed around the northwestern portion of the area while the remaining two are situated at the south central portion in an area underlain by pegmatite. Apart from these anomalous concentrations, there are other three relatively high values $(1573.3$ - 2305.7 ppm) at the south central portion which is underlain by pegmatite.

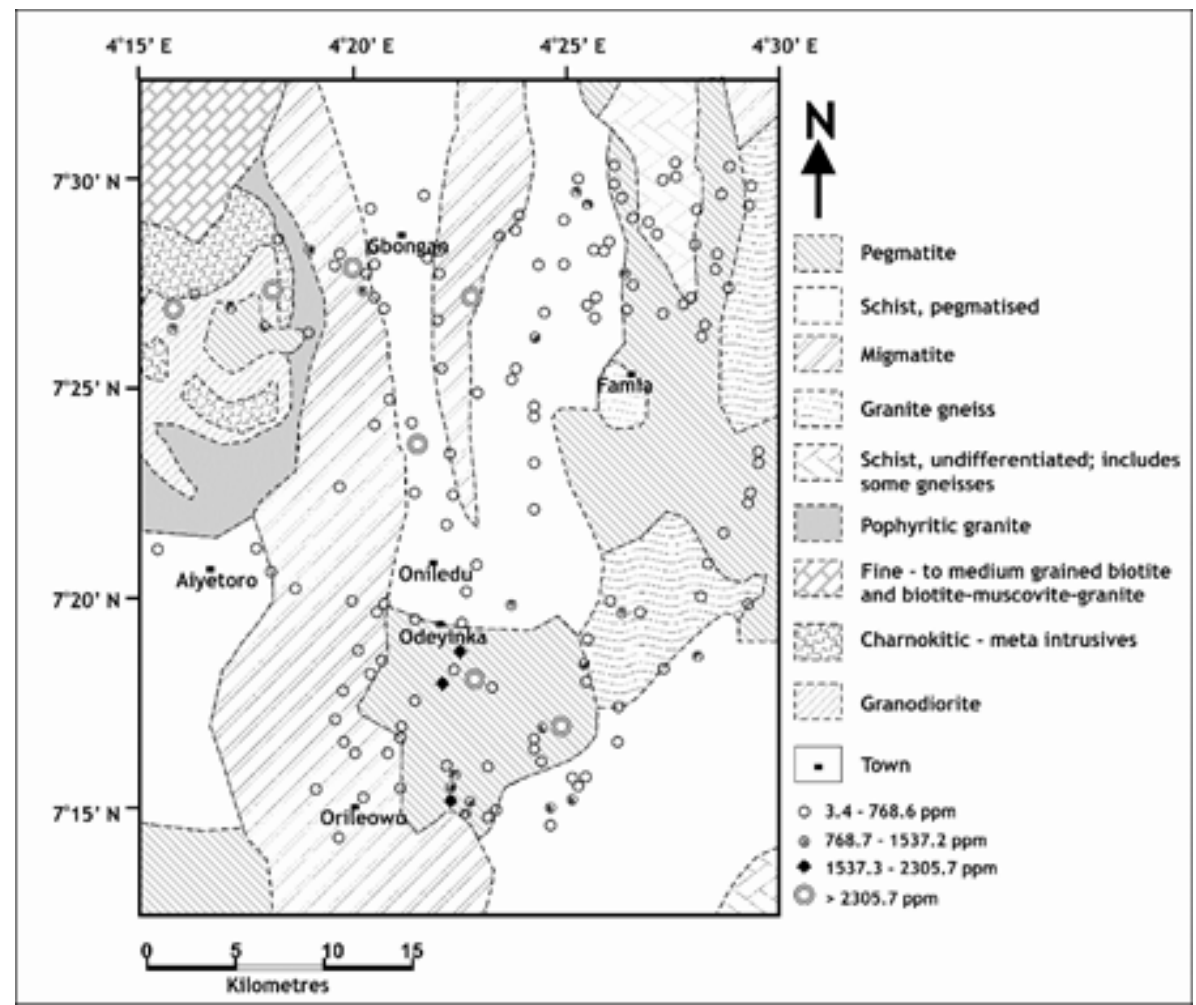

Figure 3M: Location Point Symbol Map of Zinc Distribution in Soils of Gbongan-OdeyinkaOrileowu Area.

When the average abundance of $\mathrm{Zn}$ in soil $(10-$ 200) ppm, ultramafic rocks (50 ppm), granite (40 $\mathrm{ppm})$ and granodiorite $(60 \mathrm{ppm})$ is compared with the mean value of $\mathrm{Zn}$ concentrations (510.8 ppm) in soils of the study area, the abundance of $\mathrm{Zn}$ in this area is very high. Thus, the few anomalous and relatively high values are significant. However these significant $\mathrm{Zn}$ concentrations are not considered to be related to primary $\mathrm{Zn}$ mineralization. This is because the spatial distribution pattern of $\mathrm{Zn}$ in this study is completely different from those of elements like $\mathrm{Pb}, \mathrm{Cu}$ and $\mathrm{Ag}$ with which $\mathrm{Zn}$ is expected to associate in either the base metal or precious metal deposits as mentioned earlier. This is revealed by their location point symbol maps. Consequently, one can infer that the highest proportion of $\mathrm{Zn}$ in the area might have been derived from anthropogenic sources or from a high accumulation of leaves (Adesiyan, 2010) or both. Derivation of $\mathrm{Zn}$ from leaves is not surprising as
$\mathrm{Zn}$ is an essential nutrient for almost all plants. A possible anthropogenic source of $\mathrm{Zn}$ in the study area is the pesticides which could have been used in spraying cocoa plantation, which is a common preoccupation of farmers in the study area (Fyfe, 1999 and Pfeifer et al., 2000).

In addition, a consideration of $\mathrm{Zn} / \mathrm{Cd}$ association and the ratio of the two elements in the study area tend to support the theory of anthropogenic contamination of $\mathrm{Zn}$ in the area. Normally $\mathrm{Cd}$ is associated with $\mathrm{Zn}$ in geological occurrences and the $\mathrm{Zn} / \mathrm{Cd}$ ratio is, on average, 500 to 1 , which does not deviate by more than a factor of 2 (Reimann and de Caritat, 1998; Kabata-Pendias and Pendias, 2001). However, in the study area, the $\mathrm{Zn} / \mathrm{Cd}$ ratio is 10,016 to 1 (computed from the mean values of $510.8 \mathrm{ppm}$ of $\mathrm{Zn}$ and $0.051 \mathrm{ppm}$ of $\mathrm{Cd}$ ). Such a great disparity in the $\mathrm{Zn} / \mathrm{Cd}$ ratio from the normal average (500 to 1) is not likely to be natural; hence the support for anthropogenic 
source of $\mathrm{Zn}$ in the area. Lastly, the dissimilarity between the location point symbol maps of both $\mathrm{Zn}$ and $\mathrm{Cd}$ is another possible indicator of anthropogenic source for $\mathrm{Zn}$ in the study area.

\section{CONCLUSION}

From the geochemical distribution map (the location point symbol map) of each of the elements determined in soils of the study area, diverse distribution patterns are revealed. These do not correspond perfectly with the lithological boundaries of the area as shown in the geological map 1:250,000 GSN Iwo Sheet 60 (Fig. 2). For example, the occurrence of high concentrations of $\mathrm{Ag}, \mathrm{Cd}, \mathrm{Co}, \mathrm{Cu}$ and $\mathrm{Ni}$ (at the south-central portion) in areas presumably underlain by pegmatite negate the fact that high concentration of these elements are normally associated with mafic/ultramafic lithology. This may mean that the boundaries between pegmatite and the pegmatitised schists in this area were inaccurate. The sporadic mafic schists and ultramafites reported in this area by Adesiyan (2010) could be the primary sources for elements like $\mathrm{Ni}, \mathrm{Cr}$, Co and As in the soil. There is also the possibility that the underlying rock of this part was intruded by veins containing primary mineralization of complex sulphides. Adesiyan and Adekoya (2008) reported the occurrence of similar metal dispersion patterns in the northern portion of the study area from a stream sediment survey. However, the values obtained for the concentrations of most of the elements in the present study are consistently higher. This shows the tendency of trace elements to concentrate more in soils than in stream sediments as a result of progressive dilution of elements concentration in stream sediments.

Looking at the distribution patterns of the studied trace metals, it can be inferred that the factors controlling metal dispersion in the surficial environment of the study area, are lithology, environmental influence and primary mineralization. There is the possibility of occurrence of primary Au mineralization in form of disseminations within some underlying rocks and or Au bearing quartz veins with associated complex sulphides in the area. Based on observed distribution of anomalous values of both $\mathrm{Sn}$ and $\mathrm{Au}$ on the pegmatised schists and pegmatites areas of the study area, the $\mathrm{Sn}$ is hosted by pegmatites and the Au by the schists and granite gneiss (Adesiyan, 2010 and Adesiyan et al., 2014).

As stated by some previous authors, primary gold mineralization in the Nigerian Schist Belts commonly occurs as quartz veins within several types of lithologies. At Bin Yauri, these veins commonly contain pyrite, pyrrhotite, arsenopyrite, magnetite, ilmenite, chalcopyrite, marcasite, sphalerite and galena (Akande et al., 1988, Garba and Akande, 1992; Garba, 2002). Also at Iperindo, the primary gold deposit is associated with pyrite, pyrrhotite, chalcopyrite, sphalerite and arsenopyrite (Oyinloye, 1997). Furthermore, the occurrence of primary $\mathrm{Sn}$ mineralization may not be ruled out. The $\mathrm{Sn}$ is probably hosted in the pegmatites of the area. There is a significant level of zinc pollution in the area probably due to the use of insecticides by farmers.

\section{ACKNOWLEDGEMENT}

We are grateful to Mr. Debo Adewusi of CCGVeritas Nigerian Ltd., and Mr. Henry Ogunnusi of Exxon Mobil Nigeria Ltd, for partly financing the fieldwork for this study. Immense thanks are due to the Southern and Eastern Africa Network of Analytical Chemist (SEANAC) which sponsored the laboratory analysis.

\section{REFERENCES}

Adekoya, J. A., Kehinde-Phillips, O. O. and Odukoya, A. M. 2003. Geological distribution of mineral resources in southwestern Nigeria. In: Elueze, A.A (Editor), Prospects for investment in mineral resources of southwestern Nigeria, pp. 1-13.

Adesiyan, T. A. 2010. A reconnaissance geochemical soil survey in GbonganOdeyinka-Orileowu area, Osun State, Nigeria. Unpublished M.Tech. Thesis. Federal University of Technology, Akure, Nigeria, pp. 1-23, 45-91.

Adesiyan, T. A. and Adekoya, J. A. 2008. Prospect of metallic mineralization in Gbongan area of Southwestern Nigeria. Ife Journal of Science 10(1): $151-170$.

Adesiyan, T. A., Adekoya, J. A., Akinlua A and Torto N. 2014. Statistical Studies of Soil 
Geochemical Data from GbonganOdeyinka Area, Southwestern Nigeria. Geoinformation and Geostatistics 2(1): 111124.

Adetunji, A., Olarewaju, V.O., Ganev, V.Y. and Macheva L. 2016. Geochemistry and U$\mathrm{Pb}$ Zircon geochronology of the pegmatites in Ede Area, Southwestern Nigeria: A newly discovered oldest Pan African rock in Southwestern Nigeria. Journal of |African earth Sciences 115: 177 190.

Ajayi, T. R. 1988. Integrated exploration and statistical studies of geochemical data of amphibolites in Ife-Ilesha gold field. Unpubl. Ph.D.Thesis, Obafemi Awolowo University, Ile-Ife, Nigeria. 461p.

Akande, S. O., Fakorede, O. and Mucke, A. 1988. Geology and genesis of gold-bearing quartz veins at Bin Yauri and Okolom in the Pan African domain of Western Nigeria. Geologie en Mijnboun 67: 41-51

Ako, B. D. 1980. Contribution to mineral exploration in the Precambrian Belt of part of Southwestern Nigeria. Journal of Mining and Geology 17(2):129-138.

Alao, O. 2003. Regional stream sediment geochemical survey of Odeyinka area, southwestern, Nigeria. Unpublished PGD Thesis, Federal University of Technology, Akure, Nigeria. 73p.

Alexakis, D 2008. Geochemistry of stream sediment as a tool for assessing contamination by Arsenic, Chromium and other toxic elements: East Attica region, Greece. European Water 21/22: 57-72, 2008, E. W. Production

Anozie, J. O. 1978. Geochemical stream sediment exploration in Tin-mining area near Egbe, Kwara State, Nigeria. Unpublished M.Sc. Thesis, Obafemi Awolowo University, IleIfe, $69 \mathrm{p}$.

Arisekola, T. M, Ogedengbe, O., Abimbola, A. F. and Adeniyi, O. 2011. Pegmatites of parts of Osun State (Mineralogical and Geochemical Characteristics). Occasional Paper No. 13, Nigeria Geological Survey Agency.

Chao, T. T. and Theobald, P. K. 1976. The significance of secondary iron and manganese oxides in geochemical exploration. Economic Geology 71:15601569.

Dada, S. S. 2006. Proterozoic evolution of Nigeria. In: Oshin, O. (Ed.), The Basement Complex of Nigeria and its mineral resources (A tribute to Prof. M.A. O. Rahaman). Akin Jinad \& Co. Ibadan, pp. 29-44.

de Swardt, A. M. J., Van Coppenhagen, J. D., Ogbukagu, I. K. and Hubbard, F. H. 1965. 1:250,000 Geological map of Iwo region. Geological Survey of Nigeria, Sheet 60, $1 \mathrm{p}$

El-Hinnawi, E. E., Pichler, H. and Zeil, W. 1969. Trace element distribution in Chilean Ignimbrites. Contributions to Mineralogy and Petrology 24(1): 50-62.

Elueze, A. A. 1977. Geological and geochemical studies in the Ilesha schist belt in relation to gold mineralization, Unpublished M. Phil. Thesis, University of Ibadan, Nigeria. 281p

Fletcher, K. and Doyle, P. 1974. Factors influencing trace-element distribution in the Eastern Yukon. Canadian Institute of Mining and Metallurgy Bulletin 67(741): 6165.

Freyssinet, P. 1993. Dispersion de l'or au Cours du Cuirassement Lateritique du Sud Mali: Application a la prospection geochimique. Chron. Rech. Min. No. 510, 25 - 40. In: M.C. Breedt (1995), gold exploration in tropical and sub-tropical terrain with special emphasis on Central and Western Africa.

Fyfe, W.S. 1999. Geochemistry. In: C.P. Marshall and R.W. Fairbridge (Editors.), Encyclopedia of Geochemistry. Kluwer Academic Publishers, Dordrecht, Germany, 277279.

Garba, I. and Akande, S. O. 1992. The origin and significance of non-aqueous $\mathrm{CO}_{2}$ fluid inclusions in the auriferous veins of Bin Yauri, Northwestern Nigeria. Mineralium Deposita 27:249-255.

Kabata-Pendias, A., and Pendias, H. 2001. Trace elements in soils and plants. $3^{\text {rd }}$ edition, CRC press, USA, 331 p.

Kehinde-Phillips, O. O., and Tietz, G. F. 1995. The Mineral and Geochmistry of weathering profiles over amphibolites, Antophyllite 
and Talc-Schists in the Ilesha schist belt, SW, Nigeria: Journal of Mining and Geology pp. 21-37.

Key, R. M., De Waele, B. and Liyungu, A. K. 2004. A multi-element baseline geochemical database from the western extension of the central Africa copper belt in Northwestern Zambia. Applied Earth Science (Trans. Inst. Min. Metall. B) 113:115.

Knight, K.V, lapworth, D.J, Key, R.M, Johnson, C.C, Adekanmi, M.A, Arisekola, T.M 2011. A summary report, Nigerian Geochemical mapping technical assistant project. British Geological survey commissioned report CR/10/054.150pp.

Mihaljevic, M. 1999. Zinc. In: C. P. Marshall and R. W. Fairbridge (Eds.), Encyclopedia of Geochemistry. Kluwer Academic Publishers, Dordrecht, Germany, pp.674675.

Morsy, M. 1997. Tin-rare metal mineralization near Mersa Alam. Proc. 30 ${ }^{\text {th }}$ Int'l Geol. Congr., Volume 19, pp. 225-239. In Mohamed A.MORSY, International Archives of photogrammetry and Remote sensing, Volume 32, Part B 2000.

Mosetlha, K. 2007. Microdialysis sampling, fractionation and biogeochemical studies of metal in environmental samples obtained from $\mathrm{Cu}$ and $\mathrm{Ni}$ mineralized area in Botswana. Unpublished Ph.D. Thesis, University of Botswana, Gaborone, Botswana. 113p.

Okunlola, O. A. 2006. Regional metallogeny of rare metal $(\mathrm{Ta},-\mathrm{Nb})$ mineralization in Precambrian pegmatites of Nigeria. In: O. Oshin (Editor), The Basement Complex of Nigeria and its Mineral Resources. Akin Jinad and Co., Ibadan, pp. 107-125.

Owoeye A. B. 2012. Reconnaissance geochemical studies and heavy mineral analysis of active stream sediments of Telemu-AwoEde Area of Osun State. Unpublished M.Sc. Thesis, Obafemi Awolowo University, Ile-Ife, Nigeria. 232p.

Owoeye, A. B., Ajayi, T. R., and Adesiyan, T. A. 2015. Stream Sediment Geochemistry of Telemu and its Environs: A Tool in Baseline Assessment of Mineralization Potential. Journal of Environment and Earth
Sciences, www.iiste.org, ISSN 2224-3216 (Paper) 5(8): 140-172.

Oyinloye, A. O. 1997. Ore petrology and chemical composition of gold and associated sulphides in the Iperindo primary gold deposits in Ilesha area, southwestern Nigeria: Implication on stages of mineralization. African Journal of Science and Technology 1(1): 71-81.

Pfeifer, H.R., Derron, M.H., Rey, D., Schlegel, C., Dalla Piazza, R., Dubois, J.D. and Mandia, Y. 2000. Natural trace element input to the soil-water-plant system, examples of background and contaminated situations in Switzerland, Eastern France and Northern Italy. In: Markert, B. and Friese, K. (editors), Trace metals- Their distribution and effects in the environment, pp. 33 - 86.

Plant, J. A., Smith, D., Smith, B. and Williams, L. 2001. Environmental geochemistry at 1036 the global scale. Applied geochemistry, 16, 1291-1308. In Lapworth et al . Draft paper Volume 6 [Applied Geochemistry]: Geochemical mapping using stream sediments in West-central 1 Nigeria: implications for environmental studies and mineral exploration in West Africa.

Rahaman, M. A. 1988. Recent advances in the study of the Basement Complex of Nigeria: In Oluyide, P. O., Mbonu, W. C., Ogezi, A. E., Egbuniwe, I. G., Ajibade, A. C. and Umeji, A. C. (Editors.): Precambrian Geology of Nigeria. Geological Survey of Nigeria, pp. 11-41.

Reimann, C, and De Caritat, P. 1998: Chemical Elements in the Environment. Fact sheets for the geochemist and Environmental Scientist. (Berlin: Springer-Verlag), pp. 312.

Reimann, C, and Garrette, R.G. 2005: Geochemical background - concept and reality. The Science of the Total Environment, 350(1-3): 12-27.

Reimann, C. and de Caritat P. 1998: Chemical elements in the environment - Factsheets for the geochemist and environmental scientist. Springer-Verlag, BerlinHeidelberg, 398p.

Smith, C. J., Thomas, P. and Cook, F. J. 1996. 
Accumulation of $\mathrm{Cr}, \mathrm{Pb}, \mathrm{Cu}, \mathrm{Ni}, \mathrm{Zn}$ and $\mathrm{Cd}$ in Soil following irrigation with untreated urban effluents in Australia. EnvironmentalPollution 94(3):317-323.

Smith, K. S. 1999. Cadmium. In: C.P. Marshall and R. W. Fairbridge (Eds.), Encyclopedia of Geochemistry. Kluwer Academic Publishers, Dordrecht, Germany, pp.5051.

Swiecki, R., 2005. Gold: General types of auriferous deposits according to Boyle, R.W., http://www.minelinks.

Woakes, M. and Bafor, B. E. 1983. Primary gold mineralization in Nigeria. In R. F. Foster (Editor), Gold 82: The Geology, Geochemistry and Genesis of Gold deposits. Geological Society of
Zimbabwe, Special Publication No. 1, Balkema, Rotterdam, pp. 661-672.

Woakes, M., Rahaman, M. A. and Ajibade, A. C. 1987. Some metallogenic features of the Nigerian Basement. Journal of African Earth Sciences 6(5): 655-664.

Wright, J. B., Hastings, D. A., Jones, W. B. and Williams, H. R. 1985. Geology and Mineral resources of West Africa. George Allen and Unwin (Publishers) Limited, London. 187p.

Zhai, M., Kampunzu, H. A. B., Modisi, M. P. and Totolo, O. 2003. Distribution of heavy metals in Gaborone urban soil (Botswana) and it relationship to soil pollution and bedrock composition. Environmental Geology 45: 171-180. 